The University of Southern Mississippi

The Aquila Digital Community

Faculty Publications

$9-1-2013$

\title{
Molecular Characterization of Tick Salivary Gland Glutaminyl Cyclase
}

\author{
Steven W. Adamson \\ University of Southern Mississippi, Steven.Adamson@usm.edu \\ Rebecca E. Browning \\ University of Southern Mississippi, Rebecca.Browning@eagles.usm.edu \\ Chien-Chung Chao \\ Infectious Diseases Directorate, Naval Medical Research Center \\ Robert C. Bateman Jr. \\ William Carey University, rbateman@wmcarey.edu \\ Wei-Mei Ching \\ Infectious Diseases Directorate, Naval Medical Research Center
}

See next page for additional authors

Follow this and additional works at: https://aquila.usm.edu/fac_pubs

Part of the Biology Commons

\section{Recommended Citation}

Adamson, S. W., Browning, R. E., Chao, C., Bateman, R. C., Ching, W., Karim, S. (2013). Molecular Characterization of Tick Salivary Gland Glutaminyl Cyclase. Insect Biochemistry and Molecular Biology, 43(9), 781-793.

Available at: https://aquila.usm.edu/fac_pubs/8823

This Article is brought to you for free and open access by The Aquila Digital Community. It has been accepted for inclusion in Faculty Publications by an authorized administrator of The Aquila Digital Community. For more information, please contact Joshua.Cromwell@usm.edu. 
Authors

Steven W. Adamson, Rebecca E. Browning, Chien-Chung Chao, Robert C. Bateman Jr., Wei-Mei Ching, and Shahid Karim

This article is available at The Aquila Digital Community: https://aquila.usm.edu/fac_pubs/8823 


\title{
Molecular Characterization of Tick Salivary Gland Glutaminyl Cyclase
}

\author{
Steven W. Adamson ${ }^{\mathrm{a}}$, Rebecca E. Browning ${ }^{\mathrm{a}}$, Chien-Chung Chao ${ }^{\mathrm{b}}$, Robert C. Bateman Jrc, \\ Wei-Mei Ching ${ }^{\mathrm{b}}$, and Shahid Karim ${ }^{\mathrm{a},{ }^{*}}$ \\ aDepartment of Biological Sciences, the University of Southern Mississippi, 118 College Drive \# \\ 5018, Hattiesburg, MS 39406, USA \\ bViral and Rickettsial Diseases Department, Infectious Diseases Directorate, Naval Medical \\ Research Center, Silver Spring, MD 20892 \\ ${ }^{\circ}$ College of Osteopathic Medicine, William Carey University, 498 Tuscan Avenue, Hattiesburg, \\ MS 39401, USA
}

\section{Abstract}

Glutaminyl cyclase (QC) catalyzes the cyclization of N-terminal glutamine residues into pyroglutamate. This post-translational modification extends the half-life of peptides and, in some cases, is essential in binding to their cognate receptor. Due to its potential role in the posttranslational modification of tick neuropeptides, we report the molecular, biochemical and physiological characterization of salivary gland QC during the prolonged blood-feeding of the black-legged tick (Ixodes scapularis) and the gulf-coast tick (Amblyomma maculatum). QC sequences from $I$. scapularis and $A$. maculatum showed a high degree of amino acid identity to each other and other arthropods and residues critical for zinc-binding/catalysis (D159, E202, and H330) or intermediate stabilization (E201, W207, D248, D305, F325, and W329) are conserved. Analysis of QC transcriptional gene expression kinetics depicts an upregulation during the bloodmeal of adult female ticks prior to fast feeding phases in both $I$. scapularis and A. maculatum suggesting a functional link with blood meal uptake. QC enzymatic activity was detected in saliva and extracts of tick salivary glands and midguts. Recombinant QC was shown to be catalytically active. Furthermore, knockdown of QC-transcript by RNA interference resulted in lower enzymatic activity, and small, unviable egg masses in both studied tick species as well as lower engorged tick weights for I. scapularis. These results suggest that the post-translational modification of neurotransmitters and other bioactive peptides by QC is critical to oviposition and potentially other physiological processes. Moreover, these data suggest that tick-specific QCmodified neurotransmitters/hormones or other relevant parts of this system could potentially be used as novel physiological targets for tick control.

\footnotetext{
(C) 2013 Elsevier Ltd. All rights reserved.

*Corresponding author: Shahid Karim, 118 College Drive \#5018, Hattiesburg, MS 39406, shahid.karim@ usm.edu, Phone: 601.266.6232 Fax: 601.266.5797.

Publisher's Disclaimer: This is a PDF file of an unedited manuscript that has been accepted for publication. As a service to our customers we are providing this early version of the manuscript. The manuscript will undergo copyediting, typesetting, and review of the resulting proof before it is published in its final citable form. Please note that during the production process errors may be discovered which could affect the content, and all legal disclaimers that apply to the journal pertain.

Competing Interests: The authors have declared that no competing interests exist.

${ }^{1}$ Abbreviations QC: glutaminyl cyclase; IsQC: I. scapularis QC; AmQC: A. maculatum QC; SG: salivary gland; MG: midgut
} 


\section{Keywords}

glutaminyl cyclase; RNA interference; tick neuropeptides; posttranslational modification

\section{Introduction}

Ticks are obligate blood feeders and are second only to mosquitoes in their importance as disease vectors. They are able to transmit a wide variety of pathogens, including spirochetes, rickettsia, protozoa, nematodes, and viruses (Bratton and Corey, 2005; Sonenshine, 1991; Sonenshine and Mather, 1994; Swanson et al., 2006; Vorou et al., 2007). The black-legged tick (Ixodes scapularis) is important because of its role as a vector of human disease-causing agents. I. scapularis can harbor multiple pathogens including B. burgdorferi (Burgdorfer et al., 1982), Anaplasma phagocytophilum (Telford et al., 1996), Babesia microti (Rodgers and Mather, 2007) and an encephalitis-like virus (Telford et al., 1997). The Gulf-Coast tick (Amblyomma maculatum) is known to transmit Rickettsia parkeri, which can cause a mild, febrile illness similar to Rocky Mountain spotted fever (Paddock et al., 2008; Paddock et al., 2004). Salivary glands are critical to the feeding process, and secrete numerous bioactive compounds including anticoagulants, anti-inflammatory proteins, and immunosuppressive peptides, all of which modulate tick-host interactions (Bowman et al., 1997; Sauer et al., 1995). Due to their significance in zoonotic disease transmission, the transcriptome of several tick species has been characterized by pyrosequencing expressed sequence tags (Francischetti et al., 2008; Francischetti et al., 2005; Gibson et al., 2013; Lees et al., 2010; Ribeiro et al., 2011). In our own laboratory, we have recently completed a massive EST sequencing project to define the sialotranscriptome of $A$. maculatum (Karim, 2011).

During the course of this EST sequencing project (Karim, 2011), we identified a gene with significant sequence homology to glutaminyl cyclase (QC; EC 2.3.2.5), which catalyzes the formation of pyroglutamate from $\mathrm{N}$-terminal glutamine residues (Fig. 1). Although $\mathrm{N}$ terminal glutamine residues can spontaneously cyclize, the reaction rate is three orders of magnitude lower than the enzymatically catalyzed reaction (Seifert et al., 2009). QC is a catalytically promiscuous enzyme; acting upon any $\mathrm{N}$-terminal glutamine residue, with a slight preference towards substrates which contain a bulky hydrophobic residue in the penultimate position. Originally identified from crude extracts of papaya latex, QC activity was later identified in extracts of pituitary glands, where it is involved in processing numerous neuropeptides, hormones, and cytokines during their maturation along the secretory pathway (Busby et al., 1987). Many of these regulatory peptides require an Nterminal pGlu to bind to their cognate receptor and/or to protect the N-terminus from aminopeptidase degradation (i.e. thyroid hormone-releasing hormone (TRH), gonadotropinreleasing hormone $(\mathrm{GnRH})$, monocyte chemoattractant proteins (MCPs), etc.) (Busby et al., 1987; Cynis et al., 2011; Fischer and Spiess, 1987; Hinke et al., 2000; Messer, 1963; Pohl et al., 1991; Van Coillie et al., 1998). QC is known to be involved in several pathophysiological processes in humans such as Alzheimer's disease, osteoporosis, rheumatoid arthritis, and melanoma (Gillis, 2006; Jawhar et al., 2011; Schilling et al., 2008a; Schilling et al., 2008c).

At least three tick neuropeptides have been identified which contain an N-terminal pyroglutamyl residue, which suggests that QC is critical for tick neuropeptide processing (Bissinger et al., 2011; Donohue et al., 2010; Neupert et al., 2005; Neupert et al., 2009; Simo et al., 2009a; Simo et al., 2009b). Through identifying essential physiological processes and tick molecular targets, it may be possible to interfere with these targets and prevent the spread of tick-borne diseases. In this study, we describe the functional role of $\mathrm{QC}$ in ticks through bioinformatics analysis, recombinant QC protein expression, 
immunoblotting, immunofluorescence microscopy and enzymatic studies. Furthermore, we demonstrate through RNA interference that $\mathrm{QC}$ is critically important for oviposition and embryogenesis, likely resulting from improper neuropeptide processing of QC knockdowns. This is the first study to describe the functional role of QC in blood-feeding arthropods.

\section{Methods}

\subsection{Ticks and animals}

A. maculatum and I. scapularis ticks were reared at the University of Southern Mississippi according to established methods (Patrick and Hair, 1975). Unfed ticks were maintained at room temperature and $90 \%$ relative humidity under 14/10-hour light/dark photoperiod before infestation. I. scapularis ticks were fed on rabbit ears and either allowed to feed to repletion or removed after 3-5 days depending on the experimental protocol. A. maculatum ticks were fed on sheep and either allowed to feed to repletion or removed after 5-8 days depending on the experimental protocol. Adult ticks were fed on rabbit or sheep specifically for this study and all studies with animals were performed in accordance with protocols \#10042001 and \#08110401 approved by the Institutional Animal Care and Use Committee (IACUC) at the University of Southern Mississippi.

\subsection{Bioinformatics Tools}

The full length $A$. maculatum $\mathrm{QC}$ sequence was obtained from pyrosequencing an $A$. maculatum salivary gland cDNA library (Karim, 2011). QC homologs of AmQC and IsQC were identified by BLASTP analysis of the non-redundant protein databank (Altschul et al., 1990). Selected QC sequences were aligned and graphically presented using Jalview 2.7 to highlight conserved residues and identify signal peptides, etc. (Larkin et al., 2007; Waterhouse et al., 2009). Protein secretion signals were identified using SignalP 4.0 (Bendtsen et al., 2004). The evolutionary history was inferred using the Maximum Parsimony method (Larkin et al., 2007; Tamura et al., 2011).

\subsection{Tick dissection and saliva collection}

Tick tissues were dissected in ice-cold $100 \mathrm{mM}$ MOPS buffer, pH 6.8 containing $20 \mathrm{mM}$ EGTA. After removal, salivary glands and midguts were washed gently in the same ice-cold buffer. The dissected tissues were used immediately after dissection or stored at $-70^{\circ} \mathrm{C}$ in $0.5 \mathrm{M}$ piperazine $N, N$ '-bis-2-ethane sulfonic acid, $\mathrm{pH} 6.8$, containing $20 \mathrm{mM}$ EGTA, protease inhibitor cocktail (Roche, Indianapolis, IN, USA) and 40\% glycerol. The dissected tissues were stored immediately after dissection in RNAlater (Ambion, Austin TX) prior to isolating total RNA. All other manipulations were carried out at $4^{\circ} \mathrm{C}$. Tick saliva was collected as described previously (Ribeiro et al., 1992). Dopamine and theophylline (1mM each) in $20 \mathrm{mM}$ MOPS buffered saline with $3 \%$ DMSO, pH 7.0 were injected as a stimulant for salivation (Needham and Sauer, 1979). The collected saliva was used immediately after collection or stored at $-80^{\circ} \mathrm{C}$.

\subsection{RNA preparation and cDNA synthesis}

Total RNA was isolated from midguts and salivary glands dissected from unfed and partially-fed adult female ticks using an illustra RNAspin Mini RNA isolation kit (GE Healthcare). The concentration of total RNA was determined spectrophotometrically and samples were aliquoted and stored at $-80^{\circ} \mathrm{C}$. Total RNA was reverse-transcribed using MMLV reverse transcriptase according to the manufacturers' instructions (Invitrogen). 


\subsection{Quantitation of mRNA}

Quantitative real-time PCR (QRT-PCR) was performed on a Bio-Rad C1000 Thermocycler fitted with the CFX96 Realtime System for fluorescence detection. SYBR Green PCR Mix was obtained from Fermentas (Burlington) and the manufacturer's instructions were followed. A standard curve $\left(10^{0}\right.$ to $10^{7}$ copies per reaction) was generated using each candidate gene PCR product as template. A $120 \mathrm{bp}$ QC amplicon was amplified from $I$. scapularis cDNA using IsQC-F(qrtpcr) (5'-AGGTCAGGGAGTTCATTGTGAGGT-3') and IsQC-R (qrtpcr) (5'-TGAAGGGTTCCTTCCTTGTGGAGCA-3'). A 115bp QC amplicon was amplified from $A$. maculatum cDNA using AmQC-F(qrtpcr) ( $5^{\prime}$ TGGCATCAGTGCTCAATGACAAGC-3') and AmQC-R(qrtpcr) (5'TCACTCGAGCTCCACCGTACAAAT-3'). Reactions ( $25 \mu \mathrm{l})$ containing $500 \mathrm{ng}$ of salivary gland or midgut cDNA were run under the following PCR protocol: $50^{\circ} \mathrm{C}$ for 3 minutes, $95^{\circ} \mathrm{C}$ for 10 minutes, followed by 35 cycles of $95^{\circ} \mathrm{C}$ for 15 seconds, $60^{\circ} \mathrm{C}$ for 30 seconds, $72^{\circ} \mathrm{C}$ for 30 seconds. The fluorescence was read after the final extension step. Samples were run in triplicate with no-RT and no-template controls. The copy number of candidate gene mRNA in each sample was determined using the Bio-Rad data analysis software based upon the standard curve (Browning et al., 2012).

\subsection{Protein expression analysis and western blotting}

Oligonucleotides AmQCpe2-F (5' - GTCACCTGGCACGAACTGAAG-3') and AmQCpe$\mathrm{R}$ (5'-TCAGAGCCTCAGGTACTCTGTAAGA-3') were used for amplification of the mature $A$. maculatum QC cDNA. Oligonucleotides IsQCpe2-F (5' CTCAGCTGGCATGATCTGAAGTGG- $\left.3^{\prime}\right)$ and IsQCpe-R $\left(5^{\prime}-\right.$ TCATAGCTGCAGGTACTCCGACA-3') were used for amplification of the mature $I$. scapularis $\mathrm{QC}$ cDNA. Primers for AmQC and IsQC were designed based on GenBank accessions JO841091 and XM_002415508, respectively. Both primer sets generated a 996 bp fragment. All amplifications were performed using a PCR program of $94^{\circ} \mathrm{C}$ for $1 \mathrm{~min}, 28$ cycles of $94^{\circ} \mathrm{C}$ for $1 \mathrm{~min}, 55^{\circ} \mathrm{C}$ for $1 \mathrm{~min}, 72^{\circ} \mathrm{C}$ for $1 \mathrm{~min}$, followed by $72^{\circ} \mathrm{C}$ for $7 \mathrm{~min}$. PCR products were analyzed on a $2 \%$ agarose gel stained with ethidium bromide, cloned into the pET32b vector, and transformed into chemically competent $E$. coli BL21(DE3) (EMD Biochemicals). The pET32b vector contains an $\mathrm{N}$-terminal $6 \mathrm{xHis}$ tag and a thioredoxin domain to facilitate purification and improve solubility. Plasmid DNA from positive clones was submitted to Eurofins MWG Operon for sequencing using the T7 promoter primer, to ensure a single insert was cloned in the correct orientation and reading frame. A $5 \mathrm{~mL}$ overnight culture was used to inoculate $0.5 \mathrm{~L}$ of LB containing $100 \mu \mathrm{g} / \mathrm{mL}$ amplicillin, grown to mid-log phase, and induced with $0.4 \mathrm{mM}$ IPTG, and further expressed for 20 hours at $12^{\circ} \mathrm{C}$. The cells were clarified and the recombinant protein was partially purified using Profinity IMAC Nickel charged resin (Bio-Rad). To confirm that the recombinant QC was expressed, a band was manually excised from an SDS-PAGE gel migrating at the expected molecular weight and was subjected to trypsin digestion and LC-MS/MS.

\subsection{Glutaminyl Cyclase enzyme assay}

QC activity was determined using a previously established method (Schilling et al., 2002). Briefly, the assay is a continuous fluorometric assay containing $250 \mathrm{mM} \mathrm{KCl}, 50 \mathrm{mM}$ Tris$\mathrm{HCl}$ (pH 8.0), $1 \mathrm{mM}$ Gln- $\beta \mathrm{NA}, 0.25 \mathrm{U}$ of pyroglutamyl aminopeptidase (PGAP) (Qiagen), and an appropriate amount of QC in a final volume of $250 \mu \mathrm{L}$. Reactions were initiated by the addition of QC and fluorescence was measured at $410 \mathrm{~nm}$ for 10 minutes at $30^{\circ} \mathrm{C}$. Fluorescence was monitored using a SpectraMax M3 multimodal plate reader (Molecular Devices). QC enzymatic assays of saliva were performed only with $A$. maculatum, since sufficient saliva could not be collected from I. scapularis for enzymatic assays. Soluble protein extracts from tick salivary glands and midguts were prepared by adding $100 \mu \mathrm{L}$ of Extraction Buffer (1X PBS, Protease Inhibitor Cocktail) per 10 midguts or 20 salivary 
glands. Whole tissue was disintegrated with 3-5 pulses of a sonicator and the insoluble material was separated by centrifugation at $16,000 \mathrm{xg}$ for $5 \mathrm{~min}$. The supernatant was removed and used immediately or stored at $-80^{\circ} \mathrm{C}$ for later use.

\subsection{Synthesis of dsRNA and microinjection of dsRNA into female adult ticks}

QC PCR amplicons from recombinant gene expression (Section 2.6) were joined to the T7 promoter linker using the Block-iT T7 TOPO kit (Invitrogen). The TOPO linking reaction was used as a template for a PCR reaction containing the T7 PCR primer and a gene-specific primer to produce sense and antisense linear DNA template. A transcription reaction was assembled using the BLOCK-iT RNA TOPO transcription kit. The sense and antisense ssRNA was purified, annealed, and verified in size by agarose gel electrophoresis. To investigate the role of QC in tick feeding success in vivo, 50 unfed adult female ticks were injected with 1000ng QC-dsRNA into the hemocoel using a Hamilton syringe fitted with a 33-gauge needle (Karim et al., 2004). Control ticks were injected with 1000ng GFP-dsRNA. After injection of dsRNA, ticks were kept at $37^{\circ} \mathrm{C}$ overnight under high humidity to confirm tick survival. A. maculatum ticks were infested on sheep, whereas $I$. scapularis ticks were infested on rabbit ears (Karim and Adamson, 2012).

\subsection{RNA interference phenotype}

Ticks injected with dsRNA were allowed to partially feed (8 days), and were then removed and weighed on an analytical balance. Some of the ticks injected with dsRNA were allowed to feed to repletion and the oviposition and hatching was monitored.

\subsection{Mass Spectroscopy of Samples}

Saliva was collected from adult female $A$. maculatum ticks injected with QC-dsRNA or an irrelevant gene (GFP-dsRNA), separated via a 4-20\% SDS-PAGE, and stained with Coomassie Blue. Selected spots were manually excised from the gels and washed with 100 $\mathrm{mM}$ ammonium bicarbonate buffer $(\mathrm{pH} 8.5)$ and $100 \%$ acetonitrile $(\mathrm{ACN}) \operatorname{mix}(\mathrm{v} / \mathrm{v}, 1: 1)$ until the color disappeared. The gel spots were washed with HPLC grade water followed by $100 \%$ ACN were dried in a speedvac as previously described (Chao et al., 2004). Disulfide bond reduction was performed by adding $2 \mathrm{mM}$ DTT at $60^{\circ} \mathrm{C}$ for 30 minutes followed by 3 molar ratio of iodoacetamide in the dark at room temperature. The reduced, alkylated proteins were digested with trypsin $(0.5 \mathrm{mg} / \mathrm{ml}$, Promega) using a 50:1 ratio (protein:trypsin) overnight at $37^{\circ} \mathrm{C}$. The peptides were dried in a Speedvac and resuspended in water with $0.1 \%$ formic acid to a final concentration of $1 \mathrm{mg} / \mathrm{ml}$. The digested samples were analyzed on a LTQ Vello ion-trap mass spectrometer using a method previously described (Chao et al., 2004). Protein identification was performed using the Sequest algorithm (Eng et al., 2008) in the Protein Discover 1.1 software package (Thermo Electron) and a tick database containing 3500 tick-specific polypeptides (Francischetti et al., 2009; Karim, 2011). The identified peptides were further evaluated using the charge state versus cross-correlation number (Xcorr). The criteria for positive identification of peptides were Xcorr $>1.5$ for singly charged ions, Xcorr $>2.0$ for doubly charged ions, and Xcorr $>2.5$ for triply charged ions. Only the best peptides were considered and nonspecific matches (i.e., false positive matches) were eliminated by cross-referencing rabbit and sheep databases (to eliminate any host proteins) and a reversed protein sequence database generated from the A. maculatum sialome sequence to lower the false positive rate.

\subsection{Statistics}

All data are expressed as means \pm SEM. Statistical significance was determined by the Student's $t$ test; differences in multiple comparisons among different experimental groups were determined by analysis of variance using the Tukey test. 


\section{Results}

\subsection{Multiple sequence alignment and phylogenetic relationships}

During the course of a massive EST sequencing project identifying transcripts in $A$. maculatum salivary glands (Karim, 2011), we identified an open reading frame with significant amino acid homology to Glutaminyl Cyclase (QC). QC was also found to be present in the I. scapularis genome sequencing project (GenBank ID: EEC19218.1) (Hill and Wikel, 2005). Therefore, tick QC amino acid sequences were aligned with QC sequences from several other species (Fig. 2). QC belongs to a family of related proteins that fall within the zinc peptidase-like superfamily of conserved domains (Marchler-Bauer et al., 2011). Alignment of selected QC members shows a high degree of sequence identity (40-48\%) and similarity (62-77\%) and the most conserved regions flank catalyticallyinvolved residues (Fig. 2). Tick QC sequences also possess a predicted signal peptide that supports the secretory nature of this protein. QC is found in all eukaryotic organisms examined for which genomic data is available, underscoring its universal role in catalyzing the formation of N-terminal pGlu (pyroglutamate) in peptides and proteins (Fig. 1).

AmQC has 64\% amino acid identity to IsQC and the tick QC sequences have $~ 40-48 \%$ amino acid identity to genes from Homo sapiens, Aedes aegypti, Culex quinquefasciatus, and Drosophila melanogaster. Previous work characterizing the active site of human QC shows that zinc is tetrahedrally coordinated with a water molecule, and residues D159, E202 and H330 (Fig. 2; red highlighted residues) (Huang et al., 2005). The intermediate is presumably stabilized by additional amino acids found in the active site pocket residues E201, W207, D248, D305, F325 and W329 (Fig. 2; green highlighted residues) (Huang et al., 2005). These residues are conserved in all known animal QC sequences, and are similarly conserved in ticks.

Phylogenetic analysis of the QC family shows the general expected pattern that recapitulates the species phylogeny for eukaryotic organisms, indicating that it behaves like an orthologous family. In most cases (especially in metazoans) a single gene is found per organism and this only deviates for Drosophila. The tick genes group within the arthropods as expected and were most closely related to two other blood-sucking arthropods, $C$. quinquefasciatus and $A$. aegypti (Fig. 3), further confirming their identity as QC orthologs. As has been shown before, animal QC sequences are related closer to zinc-dependent bacterial aminopeptidases (Fig. 3; Streptomyces griseus-AP and Vibrio proteolyticus-AP), than to plant or bacterial QCs, which are thought to have arisen independently through convergent evolution (Booth et al., 2004; Schilling et al., 2008b).

\subsection{Transcriptional expression of QC in tick tissues}

Tick salivary gland transcripts which are important for blood feeding are correspondingly upregulated during the bloodmeal. In both $I$. scapularis and A. maculatum salivary glands, QC transcriptional activity rapidly increases during the onset of feeding, peaking at approximately 48 hours, presumably during the slow-feeding phase (Fig. 4A-B). QC salivary gland transcripts then decrease over remaining feeding period. Since N-terminal protection prolongs the half-life of proteins, it is highly likely that part of the role of QC may be in protection of some salivary proteins/neuropeptides from endopeptidases present at the feeding site. In midguts, there is a marked difference in transcriptional profile between the two studied tick species. In $A$. maculatum, the relative copy number in midguts increases throughout the bloodmeal, peaking at $\sim 18$ higher relative copy numbers at $120 \mathrm{Hr}$ into feeding compared to the unfed $(0 \mathrm{Hr})$ stage (Fig. 4A). However, the relatively copy number in I. scapularis midguts, is highest during the unfed stage (Fig. 4B), and transcriptional activity attenuates throughout the remainder of the bloodmeal. Based on the relative copy 
numbers, it appears that that the amount of QC transcriptional activity within $A$. maculatum is considerably more dynamic than in I. scapularis. Taken together, the transcriptional activity of QC could be related to the structure/function/metabolism of tick neuropeptides which contain an $\mathrm{N}$-terminal pyroglutamyl residue.

\subsection{Recombinant protein expression}

Several attempts to express tick QC in a bacterial expression system which fused the mature protein sequence to an $\mathrm{N}$-terminal $6 \mathrm{xHis}$ tag failed to yield any soluble protein, and recent work has shown that QC solubility is apparently enhanced by glycosylation in vivo, (RuizCarrillo et al., 2011). Therefore, we cloned the mature protein sequence for AmQC and IsQC into the $\mathrm{pET} 32 \mathrm{~b}$ vector, which fuses the protein to a $20.9 \mathrm{KDa}$ thioredoxin solubility tag. This approach was previously used to successfully express human glutaminyl cyclase for crystallographic studies (Huang et al., 2005). This recombinant expression yielded 50 $\mu \mathrm{g}$ of partially purified QC per liter of culture media. Gel bands corresponding to the predicted molecular weight of the recombinant AmQC were digested with trypsin and peptide identification with mass spectroscopy generated 3 unique peptides representing 16\% sequence coverage (Fig. 5).

\subsection{Enzyme activity}

Although no immunoreactivity could be observed in saliva, a low fluorescent signal corresponding to QC activity was detected in A. maculatum saliva (Fig. 6A). Although further testing of QC activity in I. scapularis saliva was desirable, the amount of saliva that is necessary for enzymatic assays was prohibitive. However, salivary gland and midgut extracts from both tick species showed QC enzymatic activity (Fig. 6B-E). The highest enzymatic activity from tissue samples was observed in $A$. maculatum salivary gland extracts and was approximately 10 -fold higher than in $A$. maculatum midgut extracts or saliva (Fig. 6A-C). It is somewhat surprising that relatively low enzymatic activity was observed in saliva, given that tick QC sequences have an N-terminal secretion signal (Fig. 2 ), and might result from the inherent enzymatic instability, as this has been observed in purifying QC from mammalian tissues (Busby et al., 1987). Alternatively, this could result from partial proteolysis of QC given the time necessary for saliva collection.

Recombinantly expressed QC from I. scapularis and A. maculatum (Fig. 7A-B) both exhibited fluorescence increases that were proportional to the enzyme concentration, with a correlation coefficient exceeding 0.995 in all enzymatic reactions. Control reactions in which either QC or the accessory enzyme (PGAP) was absent or which contained heatdenatured recombinant enzyme showed no increases in fluorescence, indicating the enzyme activity originated from the recombinant $\mathrm{QC}$ and did not result from some inorganic factor in the enzyme solution.

\subsection{RNA interference}

Gene knockdown analysis was performed in order to further elucidate the functional importance of QC in tick tissues. Salivary glands dissected from partially fed ticks injected with $1000 \mathrm{ng}$ of QC-dsRNA demonstrated greater than 99\% decrease in gene transcript (Fig. 8A) while $\beta$-actin transcript levels remained the same in GFP-dsRNA and QC-dsRNA injected tissues. There were no observable differences in tick attachment between control and experimental groups. Unfed adult female I. scapularis ticks injected with QC-dsRNA and then allowed to partially feed on the host had a significantly lower weight (27.3mg) compared to control ticks which attained an average repletion weight of $71.9 \mathrm{mg}$ (Figs. 8BD). Unfed adult female $A$. maculatum ticks injected with QC-dsRNA and then partially-fed on the host attained an average repletion weight of $72.3 \mathrm{mg}$ compared to control ticks which attained an average repletion weight of $105.0 \mathrm{mg}$ (Figs. 8B-D). I. scapularis ticks injected 
with QC-dsRNA laid very small egg masses of normal coloration, but no larvae hatched (Figs. 8B and 9). A. maculatum ticks that were injected with QC-dsRNA laid very small egg masses, dark brown in coloration, and no larvae hatched (Figs. 8B and 9). Moreover, tick tissues injected with QC-dsRNA had significantly lower QC enzymatic activity than control tissues (Fig. 10). These data indicate that QC is functionally essential for oviposition and/or embryogenesis, resulting from impaired posttranslational processing of tick neuropeptides/ hormones.

\subsection{Analysis of salivary constituents}

Finally, the salivary protein constituents of saliva were compared between A. maculatum ticks injected with QC-dsRNA and mock-injected ticks (Fig. 11 and Supplementary Table 1). LC-MS-MS identification of peptides cross-referenced to a tick salivary protein library identified 20 proteins in control samples and 24 proteins in QC knockdowns, with only a predicted lipoprotein (Am-15345) and a WD40-domain protein (Am-31789) present in both groups (Supplementary Data 1). In both groups, there are proteins with putative functions involved in heme binding (Am-15345/Am-14816), histamine binding proteins (Am-20021/ Am-2752), nucleotide metabolism (Am-36803, Am-14339, Am-861, Am-5385, Am-156987), chromosomal maintenance (Am-39687, Am-61479), cell motility (Am-71309, Am-17465, Am-934), and many hypothetical proteins with unknown functions (Supplementary Data 1). Surprisingly, we were unable to identify any small proteins $(<15 \mathrm{kDa})$ present in the saliva of QC knockdowns, possibly resulting from higher protein turnover (Fig. 11 and Supplementary Data 1). This would be consistent with the presence of a chaperonin (Am-77283) and UDP-N-acetylglucosamine-peptide N-acetyl glucosaminyltransferase (Am-103635), both of which are involved in protein folding/ turnover and are found only in the QC-knockdowns.

\section{Discussion}

It is somewhat surprising that an enzyme responsible for neuropeptide modification would be found in salivary gland tissues. However, salivary glands are under neuronal control with neurons and axonal projections innervating tick salivary glands and terminating in type II and III acini, suggesting that neuropeptides exhibit strong regulatory control over salivary gland activity (Balashov et al., 1983; Coons and Alberti, 1999; Simo et al., 2009a; Simo et al., 2012). Moreover, one recent report showed that myoinhibitory peptide and SIFamide are produced by central neurons and delivered via axonal projections to tick salivary ducts and acini, which could be detected in both synganglia and salivary gland extracts (Simo et al., 2009b).

In the present study, we have examined the functional significance of $\mathrm{QC}$, a known neuropeptide/hormone processing enzyme, the first report characterizing QC in bloodfeeding arthropods. Multiple sequence alignment (Fig. 2) confirms that residues involved in zinc binding, intermediate stabilization, and disulfide bonding is well conserved across diverse phyla from $H$. sapiens to tick QC sequences. Phylogenetic analysis shows that tick QC sequences are most similar to mosquitoes and other insects and have diverged from vertebrates (Fig. 3). Unlike the QC from Drosophila, tick QC does not appear to be present as multiple isozymes since there was only one identified QC sequence present in the $I$. scapularis genome (Hill and Wikel, 2005; Schilling et al., 2007).

QRT-PCR data analysis shows dynamic transcriptional expression of QC throughout the bloodmeal (Fig. 4). If protein abundance mirrors the observed transcriptional profile during feeding, then QC is most abundant in salivary glands during the tick's slow-feeding period, peaking within 48 hours of attachment (Fig. 4). In contrast, QC expression may be stimulated during the tick's fast-feeding phase in $A$. maculatum midgut tissues (Fig. 4A), 
though this was not observed in I. scapularis midguts. Since the bulk of whole blood is digested in the tick's fast-feeding phase and the expression of QC in midguts is coordinately stimulated, it is possible that neuropeptide processing by QC may be involved in stimulating gut contractions and releasing proteolytic enzymes by targeting cyclization of periviscerokinin, sulfakinin and/or corazonin (Bissinger et al., 2011; Donohue et al., 2010; Nassel, 2002; Neupert et al., 2005; Neupert et al., 2009; Predel et al., 2008; Simo et al., 2009b; Veenstra, 2009; Wegener et al., 2002; Wegener et al., 2001).

Surprisingly, a prominent effect on engorged tick weight was observed with I. scapularis (Fig. 8B), despite the fact that the transcriptional expression of QC in I. scapularis was at the lowest levels during the late-feeding stage (Fig. 4B). The observed lack of difference in engorged tick weight in $A$. maculatum tissues could have resulted from the so-called "dilution effect" that occurs with injected dsRNA during the late stages of feeding (Karim and Adamson, 2012). Alternatively, this suggests that pGlu-modified neuropeptides, which are possibly involved in bloodmeal digestion, do not significantly impact tick engorgement. It is noteworthy that the specific activity of QC in salivary gland extracts was approximately four-fold higher than in midgut extracts, though this was not observed in I. scapularis (Fig. 6). Given the observed differences in QC transcriptional expression between salivary glands and midguts over the bloodmeal (Fig. 4), and the observed differences in specific activity between salivary and midgut extracts (Fig. 6), it seems likely that pGlu-modification is spatially and temporally linked to QC activity.

Tryptic digests of recombinant $\mathrm{QC}$ predict the peptides as originating from A. maculatum QC (Fig. 5). Moreover, enzymatic activity is observed with tick saliva, salivary and midgut extracts, and recombinantly expressed QC (Fig. 6-7), strongly arguing this protein is catalytically active in vivo.

QC knockdown may have influenced neuropeptide metabolism in three different manners. First, QC knockdown may have resulted in tick neuropeptides with shortened half-lives. It has previously been shown that pyroglutamated GnRH and MCP-2 have a longer serum half-life than their uncapped counterparts, in part to their enhanced resistance to proteases, and this is believed to be a general phenomenon (Morty et al., 2006; Van Coillie et al., 1998; Wang et al., 2009). This may explain why no peptides $(<15 \mathrm{kDa})$ were identified in saliva collected from ticks injected with QC-dsRNA (Fig. 11, Supplementary Table 1). Second, some neuropeptides, such as $\mathrm{GnRH}$ and $\mathrm{MCP}$, require the pyroglutamyl residue to correctly bind to their receptor. Finally, QC knockdown may result in an improper balance of blocked/unblocked neuropeptides. A PVK homolog in A. aegypti (CAPA-PVK-2) was shown to have a blocked/unblocked ratio of 5:1 in abdominal ganglia but 1:4 in the brain. Similarly, the ratio of blocked to unblocked allatostatin-C was 3:1 in the abdominal and thoracic ganglia and 1:2 in the brain and dorso-caudal neuropil of the terminal ganglia (Predel et al., 2010). Indeed, since QC is catalytically promiscuous and there are multiple physiological targets, these mechanisms are likely not mutually exclusive and may operate cooperatively depending on tick physiology. Certainly, the challenge in this study is to associate the observed reduction of fecundity in QC knockdowns (Figs. 8-9) with the impact on neuropeptide processing.

Not surprisingly, insect neuropeptides have been extensively characterized in other model systems, and have predicted several neuropeptides that contain an N-terminal pGlu, but most identification of tick neuropeptides is based on in silico searches (Audsley and Weaver, 2009; Nassel, 2002; Neupert and Predel, 2005; Neupert et al., 2009; Predel et al., 2010; Predel et al., 2008). With regard to tick pGlu-neuropeptides, a recent MALDI-TOF study analyzing tick synganglia detected corazonin and periviscerokinin (PVK) with the corresponding N-terminus in the cyclized form (Neupert et al., 2005; Neupert et al., 2009). 
Though the peptide sequence of sulfakinin was not determined to be blocked with pGlu, it is likely cyclized in vivo given the presence of an N-terminal Gln. Furthermore, both in silico reports and mass spectroscopy confirm the presence of pGlu neuropeptides in tick synganglia, including corazonin, sulfakinin, and periviscerokinin (Christie, 2008; Donohue et al., 2010).

Sulfakinin bears structural homology to the vertebrate gastrin/cholecystokinin peptide family that signals satiety and appears to regulate food seeking and feeding (Nassel, 2002). In the German cockroach (Blattella germanica), sulfakinin increased the frequency of contractions of both foregut and hindgut (Maestro et al., 2001). It was discovered to inhibit food uptake in locusts, crickets, cockroaches and flies and stimulate the release of digestive enzymes into the gut (Audsley and Weaver, 2009; Kastin, 2006). PVKs have been studied most extensively in cockroaches, where it appears that they stimulate contractions in the foregut and hyperneural muscle (Nassel, 2002; Wegener et al., 2001). PVKs also seem to be involved in the regulation of water balance, which is significant since osmotic balance is maintained by the salivary glands in ticks, instead of Malphigian tubules in other insects (Kemp et al., 1982; Neupert and Predel, 2005; Neupert et al., 2005; Wegener et al., 2002). Corazonin shares some sequence identity with the adipokinetic hormone (AKH) family, and especially the hypertrehalosaemic hormone and binds to a receptor belonging to the $\mathrm{GnRH}$ receptor family (Cazzamali et al., 2002; Nassel, 2002; Park et al., 2002). A wide range of behaviors are attributed to corazonin, but they can be unified by considering them part of a stress response pathway (Bissinger et al., 2011; Veenstra, 2009). Moreover, the similarities between mammalian GnRH and corazonin suggest that corazonin may be modulated by other stress hormones, impacting behavioral and physiological responses to stress.

\section{Conclusions}

In this work, we have provided evidence that $\mathrm{QC}$ is enzymatically active in two tick species and is likely involved in the posttranslational modification of neuropeptides. Bloodmeal feeding induced QC gene expression, suggesting an important role in the posttranslational modification of key neuropeptides in both tick species. Disruption of QC in tick via RNA interference, resulted in impaired oviposition and larvae were inviable. QC is a catalytically promiscuous enzyme and it is difficult to assign the observed phenotype to higher turnover or impaired binding of any one particular pGlu neuropeptide, and it is possible there are other as yet unidentified tick pGlu-modified proteins that may also have been influenced by QC knockdown. The posttranslational formation of pyroglutamyl residues on tick neuropeptides is poorly understood in relation to how they regulate blood feeding, embryogenesis, and oviposition, including why arthropods concurrently possess multiple copies that stimulate (e.g. proctolin, allatotropin, sulfakinins and tachykinins) and inhibit (myosuppressins, myoinhibitory peptides, and allatostatins) gut peristaltic movement and oviposition (Audsley and Weaver, 2009). It seems reasonable to speculate that the reduction in fecundity may have resulted from impaired feeding, at least in I. scapularis, since sulfakinin and PVK stimulate gastric contractions and release proteolytic enzymes, which may have led to nutrient levels that did not support the synthesis of yolk proteins (Boldbaatar et al., 2010; Hatta et al., 2007). It is also possible that the function of corazonin may have been impaired, resulting in an inability to maintain homeostasis needed during feeding, which is the nadir of osmotic and oxidative stress in the tick lifecycle (Citelli et al., 2007; Graca-Souza et al., 2006). The impact of QC knockdown on these three neuropeptides or others may have had a synergistic effect on feeding and fecundity. We have proposed a putative model (Fig. 12) for the interactions between pGlu-neuropeptides present in ticks and the mechanisms by which they may influence feeding, nutrient availability, oviposition, and stress responses. 


\section{Supplementary Material}

Refer to Web version on PubMed Central for supplementary material.

\section{Acknowledgments}

This work was partly supported by American Heart Association award 09SDG2280207 and US DOS award PGAP21049 to SK. We thank Khem Raj BC, Baobin Kang and Lacey Sipsey for technical support; MS-INBRE core facility is supported by the National Center for Research Resources (5P20RR016476-11) and the National Institute of General Medical Sciences (8 P20 GM103476-11) from the National Institutes of Health.

Since CC and WMC are government employees and this is a government work, the work is in the public domain of the United States. Notwithstanding any other agreements, the NMRC reserves the right to provide the work to PubMedCentral for display and use by the public, and PubMedCentral may tag or modify the work consistent with its customary practices. You can establish rights outside of the U.S. subject to a government use license.

\section{References}

Altschul SF, Gish W, Miller W, Myers EW, Lipman DJ. Basic local alignment search tool. J Mol Biol. 1990; 215:403-410. [PubMed: 2231712]

Audsley N, Weaver RJ. Neuropeptides associated with the regulation of feeding in insects. Gen Comp Endocrinol. 2009; 162:93-104. [PubMed: 18775723]

Balashov, IUS.; Raikhel, AS.; Hoogstraal, H. An atlas of ixodid tick ultrastructure. Entomomological Society of America; Washington D.C: 1983.

Bendtsen JD, Nielsen H, von Heijne G, Brunak S. Improved prediction of signal peptides: SignalP 3.0. J Mol Biol. 2004; 340:783-795. [PubMed: 15223320]

Bissinger BW, Donohue KV, Khalil SM, Grozinger CM, Sonenshine DE, Zhu J, Roe RM. Synganglion transcriptome and developmental global gene expression in adult females of the American dog tick, Dermacentor variabilis (Acari: Ixodidae). Insect molecular biology. 2011; 20:465-491. [PubMed: 21689185]

Boldbaatar D, Umemiya-Shirafuji R, Liao M, Tanaka T, Xuan X, Fujisaki K. Multiple vitellogenins from the Haemaphysalis longicornis tick are crucial for ovarian development. J Insect Physiol. 2010; 56:1587-1598. [PubMed: 20576517]

Booth RE, Lovell SC, Misquitta SA, Bateman RC Jr. Human glutaminyl cyclase and bacterial zinc aminopeptidase share a common fold and active site. BMC Biol. 2004; 2:2. [PubMed: 15028118]

Bowman AS, Gengler CL, Surdick MR, Zhu K, Essenberg RC, Sauer JR, Dillwith JW. A novel phospholipase A2 activity in saliva of the lone star tick, Amblyomma americanum (L.). Exp Parasitol. 1997; 87:121-132. [PubMed: 9326887]

Bratton RL, Corey R. Tick-borne disease. Am Fam Physician. 2005; 71:2323-2330. [PubMed: 15999870]

Browning R, Adamson SW, Karim S. Choice of a stable set of reference genes for qRT-PCR analysis in the Gulf-Coast tick (Amblyomma maculatum). Insect Biochem Mol Biol. 2012 In Press.

Burgdorfer W, Barbour AG, Hayes SF, Benach JL, Grunwaldt E, Davis JP. Lyme disease-a tick-borne spirochetosis? Science. 1982; 216:1317-1319. [PubMed: 7043737]

Busby WH Jr. Quackenbush GE, Humm J, Youngblood WW, Kizer JS. An enzyme(s) that converts glutaminyl-peptides into pyroglutamyl-peptides. Presence in pituitary, brain, adrenal medulla, and lymphocytes. The Journal of biological chemistry. 1987; 262:8532-8536. [PubMed: 3597387]

Cazzamali G, Saxild N, Grimmelikhuijzen C. Molecular cloning and functional expression of a Drosophila corazonin receptor. Biochemical and biophysical research communications. 2002; 298:31-36. [PubMed: 12379215]

Chao CC, Chelius D, Zhang T, Daggle L, Ching WM. Proteome analysis of Madrid E strain of Rickettsia prowazekii. Proteomics. 2004; 4:1280-1292. [PubMed: 15188395]

Christie AE. Neuropeptide discovery in Ixodoidea: an in silico investigation using publicly accessible expressed sequence tags. Gen Comp Endocrinol. 2008; 157:174-185. [PubMed: 18495123] 
Citelli M, Lara FA, da Silva Vaz I Jr. Oliveira PL. Oxidative stress impairs heme detoxification in the midgut of the cattle tick, Rhipicephalus (Boophilus) microplus. Mol Biochem Parasitol. 2007; 151:81-88. [PubMed: 17123644]

Coons, LB.; Alberti, G. The acari-ticks. In: Harrison, FW.; Foelix, R., editors. Microscopic anatomy of invertebrates. Wiley-Liss; New York: 1999. p. 267-514.

Cynis H, Hoffmann T, Friedrich D, Kehlen A, Gans K, Kleinschmidt M, Rahfeld JU, Wolf R, Wermann M, Stephan A, Haegele M, Sedlmeier R, Graubner S, Jagla W, Muller A, Eichentopf R, Heiser U, Seifert F, Quax PH, de Vries MR, Hesse I, Trautwein D, Wollert U, Berg S, Freyse EJ, Schilling S, Demuth HU. The isoenzyme of glutaminyl cyclase is an important regulator of monocyte infiltration under inflammatory conditions. EMBO Mol Med. 2011

Donohue KV, Khalil SM, Ross E, Grozinger CM, Sonenshine DE, Michael Roe R. Neuropeptide signaling sequences identified by pyrosequencing of the American dog tick synganglion transcriptome during blood feeding and reproduction. Insect biochemistry and molecular biology. 2010; 40:79-90. [PubMed: 20060044]

Eng JK, Fischer B, Grossmann J, Maccoss MJ. A fast SEQUEST cross correlation algorithm. J Proteome Res. 2008; 7:4598-4602. [PubMed: 18774840]

Fischer WH, Spiess J. Identification of a mammalian glutaminyl cyclase converting glutaminyl into pyroglutamyl peptides. Proc Natl Acad Sci U S A. 1987; 84:3628-3632. [PubMed: 3473473]

Francischetti IM, Meng Z, Mans BJ, Gudderra N, Hall M, Veenstra TD, Pham VM, Kotsyfakis M, Ribeiro JM. An insight into the salivary transcriptome and proteome of the soft tick and vector of epizootic bovine abortion, Ornithodoros coriaceus. J Proteomics. 2008; 71:493-512. [PubMed: 18725333]

Francischetti IM, My Pham V, Mans BJ, Andersen JF, Mather TN, Lane RS, Ribeiro JM. The transcriptome of the salivary glands of the female western black-legged tick Ixodes pacificus (Acari: Ixodidae). Insect biochemistry and molecular biology. 2005; 35:1142-1161. [PubMed: 16102420]

Francischetti IM, Sa-Nunes A, Mans BJ, Santos IM, Ribeiro JM. The role of saliva in tick feeding. Front Biosci. 2009; 14:2051-2088.

Gibson AK, Smith Z, Fuqua C, Clay K, Colbourne JK. Why so many unknown genes? Partitioning orphans from a representative transcriptome of the lone star tick Amblyomma americanum. BMC Genomics. 2013; 14:135. [PubMed: 23445305]

Gillis JS. Microarray evidence of glutaminyl cyclase gene expression in melanoma: implications for tumor antigen specific immunotherapy. J Transl Med. 2006; 4:27. [PubMed: 16820060]

Graca-Souza AV, Maya-Monteiro C, Paiva-Silva GO, Braz GR, Paes MC, Sorgine MH, Oliveira MF, Oliveira PL. Adaptations against heme toxicity in blood-feeding arthropods. Insect biochemistry and molecular biology. 2006; 36:322-335. [PubMed: 16551546]

Hatta T, Umemiya R, Liao M, Gong H, Harnnoi T, Tanaka M, Miyoshi T, Boldbaatar D, Battsetseg B, Zhou J, Xuan X, Tsuji N, Taylor D, Fujisaki K. RNA interference of cytosolic leucine aminopeptidase reduces fecundity in the hard tick, Haemaphysalis longicornis. Parasitol Res. 2007; 100:847-854. [PubMed: 17136388]

Hill CA, Wikel SK. The Ixodes scapularis Genome Project: an opportunity for advancing tick research. Trends Parasitol. 2005; 21:151-153. [PubMed: 15780833]

Hinke SA, Pospisilik JA, Demuth HU, Mannhart S, Kuhn-Wache K, Hoffmann T, Nishimura E, Pederson RA, McIntosh CH. Dipeptidyl peptidase IV (DPIV/CD26) degradation of glucagon. Characterization of glucagon degradation products and DPIV-resistant analogs. The Journal of biological chemistry. 2000; 275:3827-3834. [PubMed: 10660533]

Huang KF, Liu YL, Wang AH. Cloning, expression, characterization, and crystallization of a glutaminyl cyclase from human bone marrow: a single zinc metalloenzyme. Protein Expr Purif. 2005; 43:65-72. [PubMed: 16084398]

Jawhar S, Wirths O, Bayer TA. Pyroglutamate amyloid-beta (Abeta): a hatchet man in Alzheimer disease. The Journal of biological chemistry. 2011; 286:38825-38832. [PubMed: 21965666]

Karim, S.; Adamson, SW. RNA Interference in Ticks: A Functional Genomics Tool for the Study of Physiology. In: Jockusch, EL., editor. Small RNAs: Their Diversity, Roles, and Practical Uses. Elsevier; Storrs: 2012. 
Karim S, Ramakrishnan VG, Tucker JS, Essenberg RC, Sauer JR. Amblyomma americanum salivary glands: double-stranded RNA-mediated gene silencing of synaptobrevin homologue and inhibition of PGE2 stimulated protein secretion. Insect biochemistry and molecular biology. 2004; 34:407413. [PubMed: 15041024]

Karim S, Singh P, Ribeiro JM. A deep insight into the sialotranscriptome of the gulf coast tick, Amblyomma maculatum. PloS one. 2011; 6:e28525. [PubMed: 22216098]

Karim S, Singh P, Ribeiro JMC. A Deep Insight into the Sialotranscriptome of the Gulf Coast Tick, Amblyomma maculatum. PloS one. 2011; 6:e28525. [PubMed: 22216098]

Kastin, AJ. Handbook of biologically active peptides. Academic Press; Amsterdam; Boston: 2006.

Kemp, DH.; Stone, BF.; Binnington, KC. Tick Attachment and Feeding: Role of the Mouthparts, Feeding Apparatus, Salivary Gland Secretions and the Host Response. In: Obenchain, FD.; Galun, R., editors. Physiology of Ticks. Pergamon Press; Elmsford: 1982. p. 119-168.

Larkin MA, Blackshields G, Brown NP, Chenna R, McGettigan PA, McWilliam H, Valentin F, Wallace IM, Wilm A, Lopez R, Thompson JD, Gibson TJ, Higgins DG. Clustal W and Clustal X version 2.0. Bioinformatics. 2007; 23:2947-2948. [PubMed: 17846036]

Lees K, Woods DJ, Bowman AS. Transcriptome analysis of the synganglion from the brown dog tick, Rhipicephalus sanguineus. Insect molecular biology. 2010; 19:273-282. [PubMed: 20002796]

Maestro JL, Aguilar R, Pascual N, Valero ML, Piulachs MD, Andreu D, Navarro I, Belles X. Screening of antifeedant activity in brain extracts led to the identification of sulfakinin as a satiety promoter in the German cockroach. Are arthropod sulfakinins homologous to vertebrate gastrinscholecystokinins? Eur J Biochem. 2001; 268:5824-5830. [PubMed: 11722569]

Marchler-Bauer A, Lu S, Anderson JB, Chitsaz F, Derbyshire MK, DeWeese-Scott C, Fong JH, Geer LY, Geer RC, Gonzales NR, Gwadz M, Hurwitz DI, Jackson JD, Ke Z, Lanczycki CJ, Lu F, Marchler GH, Mullokandov M, Omelchenko MV, Robertson CL, Song JS, Thanki N, Yamashita RA, Zhang D, Zhang N, Zheng C, Bryant SH. CDD: a Conserved Domain Database for the functional annotation of proteins. Nucleic Acids Res. 2011; 39:D225-229. [PubMed: 21109532]

Messer M. Enzymatic cyclization of L-glutamine and L-glutaminyl peptides. Nature. 1963; 197:1299. [PubMed: 13935130]

Morty RE, Bulau P, Pelle R, Wilk S, Abe K. Pyroglutamyl peptidase type I from Trypanosoma brucei: a new virulence factor from African trypanosomes that de-blocks regulatory peptides in the plasma of infected hosts. Biochem J. 2006; 394:635-645. [PubMed: 16248854]

Nassel DR. Neuropeptides in the nervous system of Drosophila and other insects: multiple roles as neuromodulators and neurohormones. Prog Neurobiol. 2002; 68:1-84. [PubMed: 12427481]

Needham GR, Sauer JR. Involvement of calcium and cyclic AMP in controlling ixodid tick salivary fluid secretion. J Parasitol. 1979; 65:531-542. [PubMed: 229203]

Neupert S, Predel R. Mass spectrometric analysis of single identified neurons of an insect. Biochemical and biophysical research communications. 2005; 327:640-645. [PubMed: 15649394]

Neupert S, Predel R, Russell WK, Davies R, Pietrantonio PV, Nachman RJ. Identification of tick periviscerokinin, the first neurohormone of Ixodidae: single cell analysis by means of MALDITOF/TOF mass spectrometry. Biochemical and biophysical research communications. 2005; 338:1860-1864. [PubMed: 16289040]

Neupert S, Russell WK, Predel R, Russell DH, Strey OF, Teel PD, Nachman RJ. The neuropeptidomics of Ixodes scapularis synganglion. J Proteomics. 2009; 72:1040-1045. [PubMed: 19540946]

Paddock CD, Finley RW, Wright CS, Robinson HN, Schrodt BJ, Lane CC, Ekenna O, Blass MA, Tamminga CL, Ohl CA, McLellan SL, Goddard J, Holman RC, Openshaw JJ, Sumner JW, Zaki SR, Eremeeva ME. Rickettsia parkeri rickettsiosis and its clinical distinction from Rocky Mountain spotted fever. Clin Infect Dis. 2008; 47:1188-1196. [PubMed: 18808353]

Paddock CD, Sumner JW, Comer JA, Zaki SR, Goldsmith CS, Goddard J, McLellan SL, Tamminga CL, Ohl CA. Rickettsia parkeri: a newly recognized cause of spotted fever rickettsiosis in the United States. Clin Infect Dis. 2004; 38:805-811. [PubMed: 14999622]

Park Y, Kim YJ, Adams ME. Identification of G protein-coupled receptors for Drosophila PRXamide peptides, CCAP, corazonin, and AKH supports a theory of ligand-receptor coevolution. Proc Natl Acad Sci U S A. 2002; 99:11423-11428. [PubMed: 12177421] 
Patrick CD, Hair JA. Laboratory rearing procedures and equipment for multi-host ticks (Acarina: Ixodidae). Journal of medical entomology. 1975; 12:389-390. [PubMed: 1181449]

Pohl T, Zimmer M, Mugele K, Spiess J. Primary structure and functional expression of a glutaminyl cyclase. Proc Natl Acad Sci U S A. 1991; 88:10059-10063. [PubMed: 1946423]

Predel R, Neupert S, Garczynski SF, Crim JW, Brown MR, Russell WK, Kahnt J, Russell DH, Nachman RJ. Neuropeptidomics of the mosquito Aedes aegypti. J Proteome Res. 2010; 9:20062015. [PubMed: 20163154]

Predel R, Russell WK, Russell DH, Lopez J, Esquivel J, Nachman RJ. Comparative peptidomics of four related hemipteran species: pyrokinins, myosuppressin, corazonin, adipokinetic hormone, sNPF, and periviscerokinins. Peptides. 2008; 29:162-167. [PubMed: 18201800]

Ribeiro JM, Anderson JM, Manoukis NC, Meng Z, Francischetti IM. A further insight into the sialome of the tropical bont tick, Amblyomma variegatum. BMC Genomics. 2011; 12:136. [PubMed: 21362191]

Ribeiro JM, Evans PM, MacSwain JL, Sauer J. Amblyomma americanum: characterization of salivary prostaglandins E2 and F2 alpha by RP-HPLC/bioassay and gas chromatography-mass spectrometry. Exp Parasitol. 1992; 74:112-116. [PubMed: 1730268]

Rodgers SE, Mather TN. Human Babesia microti incidence and Ixodes scapularis distribution, Rhode Island, 1998-2004. Emerg Infect Dis. 2007; 13:633-635. [PubMed: 17553286]

Ruiz-Carrillo D, Koch B, Parthier C, Wermann M, Dambe T, Buchholz M, Ludwig HH, Heiser U, Rahfeld JU, Stubbs MT, Schilling S, Demuth HU. Structures of glycosylated mammalian glutaminyl cyclases reveal conformational variability near the active center. Biochemistry. 2011; 50:6280-6288. [PubMed: 21671571]

Sauer JR, McSwain JL, Bowman AS, Essenberg RC. Tick salivary gland physiology. Annu Rev Entomol. 1995; 40:245-267. [PubMed: 7810988]

Schilling S, Appl T, Hoffmann T, Cynis H, Schulz K, Jagla W, Friedrich D, Wermann M, Buchholz M, Heiser U, von Horsten S, Demuth HU. Inhibition of glutaminyl cyclase prevents pGlu-Abeta formation after intracortical/hippocampal microinjection in vivo/in situ. J Neurochem. 2008a; 106:1225-1236. [PubMed: 18627432]

Schilling S, Hoffmann T, Wermann M, Heiser U, Wasternack C, Demuth HU. Continuous spectrometric assays for glutaminyl cyclase activity. Anal Biochem. 2002; 303:49-56. [PubMed: 11906150]

Schilling S, Lindner C, Koch B, Wermann M, Rahfeld JU, von Bohlen A, Rudolph T, Reuter G, Demuth HU. Isolation and characterization of glutaminyl cyclases from Drosophila: evidence for enzyme forms with different subcellular localization. Biochemistry. 2007; 46:10921-10930. [PubMed: 17722885]

Schilling S, Wasternack C, Demuth HU. Glutaminyl cyclases from animals and plants: a case of functionally convergent protein evolution. Biol Chem. 2008b; 389:983-991. [PubMed: 18979624]

Schilling S, Zeitschel U, Hoffmann T, Heiser U, Francke M, Kehlen A, Holzer M, Hutter-Paier B, Prokesch M, Windisch M, Jagla W, Schlenzig D, Lindner C, Rudolph T, Reuter G, Cynis H, Montag D, Demuth HU, Rossner S. Glutaminyl cyclase inhibition attenuates pyroglutamate Abeta and Alzheimer's disease-like pathology. Nat Med. 2008c; 14:1106-1111. [PubMed: 18836460]

Seifert F, Schulz K, Koch B, Manhart S, Demuth HU, Schilling S. Glutaminyl cyclases display significant catalytic proficiency for glutamyl substrates. Biochemistry. 2009; 48:11831-11833. [PubMed: 19921850]

Simo L, Slovak M, Park Y, Zitnan D. Identification of a complex peptidergic neuroendocrine network in the hard tick, Rhipicephalus appendiculatus. Cell Tissue Res. 2009a; 335:639-655. [PubMed: 19082627]

Simo L, Zitnan D, Park Y. Two novel neuropeptides in innervation of the salivary glands of the blacklegged tick, Ixodes scapularis: myoinhibitory peptide and SIFamide. J Comp Neurol. 2009b; 517:551-563. [PubMed: 19824085]

Simo L, Zitnan D, Park Y. Neural control of salivary glands in ixodid ticks. J Insect Physiol. 2012; 58:459-466. [PubMed: 22119563]

Sonenshine, DE. Biology of ticks. Oxford University Press; New York: 1991. 
Sonenshine, DE.; Mather, TN. Ecological dynamics of tick-borne zoonoses. Oxford University Press; New York: 1994.

Swanson SJ, Neitzel D, Reed KD, Belongia EA. Coinfections acquired from ixodes ticks. Clin Microbiol Rev. 2006; 19:708-727. [PubMed: 17041141]

Tamura K, Peterson D, Peterson N, Stecher G, Nei M, Kumar S. MEGA5: molecular evolutionary genetics analysis using maximum likelihood, evolutionary distance, and maximum parsimony methods. Mol Biol Evol. 2011; 28:2731-2739. [PubMed: 21546353]

Telford SR 3rd, Armstrong PM, Katavolos P, Foppa I, Garcia AS, Wilson ML, Spielman A. A new tick-borne encephalitis-like virus infecting New England deer ticks, Ixodes dammini. Emerg Infect Dis. 1997; 3:165-170. [PubMed: 9204297]

Telford SR 3rd, Dawson JE, Katavolos P, Warner CK, Kolbert CP, Persing DH. Perpetuation of the agent of human granulocytic ehrlichiosis in a deer tick-rodent cycle. Proc Natl Acad Sci U S A. 1996; 93:6209-6214. [PubMed: 8650245]

Van Coillie E, Proost P, Van Aelst I, Struyf S, Polfliet M, De Meester I, Harvey DJ, Van Damme J, Opdenakker G. Functional comparison of two human monocyte chemotactic protein-2 isoforms, role of the amino-terminal pyroglutamic acid and processing by CD26/dipeptidyl peptidase IV. Biochemistry. 1998; 37:12672-12680. [PubMed: 9730840]

Veenstra JA. Does corazonin signal nutritional stress in insects? Insect biochemistry and molecular biology. 2009; 39:755-762. [PubMed: 19815069]

Vorou RM, Papavassiliou VG, Tsiodras S. Emerging zoonoses and vector-borne infections affecting humans in Europe. Epidemiol Infect. 2007; 135:1231-1247. [PubMed: 17445320]

Wang H, Piatkov KI, Brower CS, Varshavsky A. Glutamine-specific N-terminal amidase, a component of the N-end rule pathway. Mol Cell. 2009; 34:686-695. [PubMed: 19560421]

Waterhouse AM, Procter JB, Martin DM, Clamp M, Barton GJ. Jalview Version 2--a multiple sequence alignment editor and analysis workbench. Bioinformatics. 2009; 25:1189-1191. [PubMed: 19151095]

Wegener C, Herbert Z, Eckert M, Predel R. The periviscerokinin (PVK) peptide family in insects: evidence for the inclusion of CAP(2b) as a PVK family member. Peptides. 2002; 23:605-611. [PubMed: 11897378]

Wegener C, Linde D, Eckert M. Periviscerokinins in cockroaches: release, localization, and taxonspecific action on the hyperneural muscle. Gen Comp Endocrinol. 2001; 121:1-12. [PubMed: $11161765]$ 


\section{Highlights}

- Two tick QC sequences had all the conserved residues involved in catalysis and intermediate stabilization.

- $\mathrm{QC}$ gene expression kinetics suggest a functional link between QC activity and blood meal uptake.

- QC enzymatic activity was detected in tick extracts, saliva, and by recombinant tick QC.

- $\quad$ Ticks injected with QC-dsRNA laid small, inviable egg masses, suggesting QC is critical for embryogenesis.

- These data suggest a functionally significant role for the pyroglutamation of corazonin, sulfakinin, and periviscerokinin. 


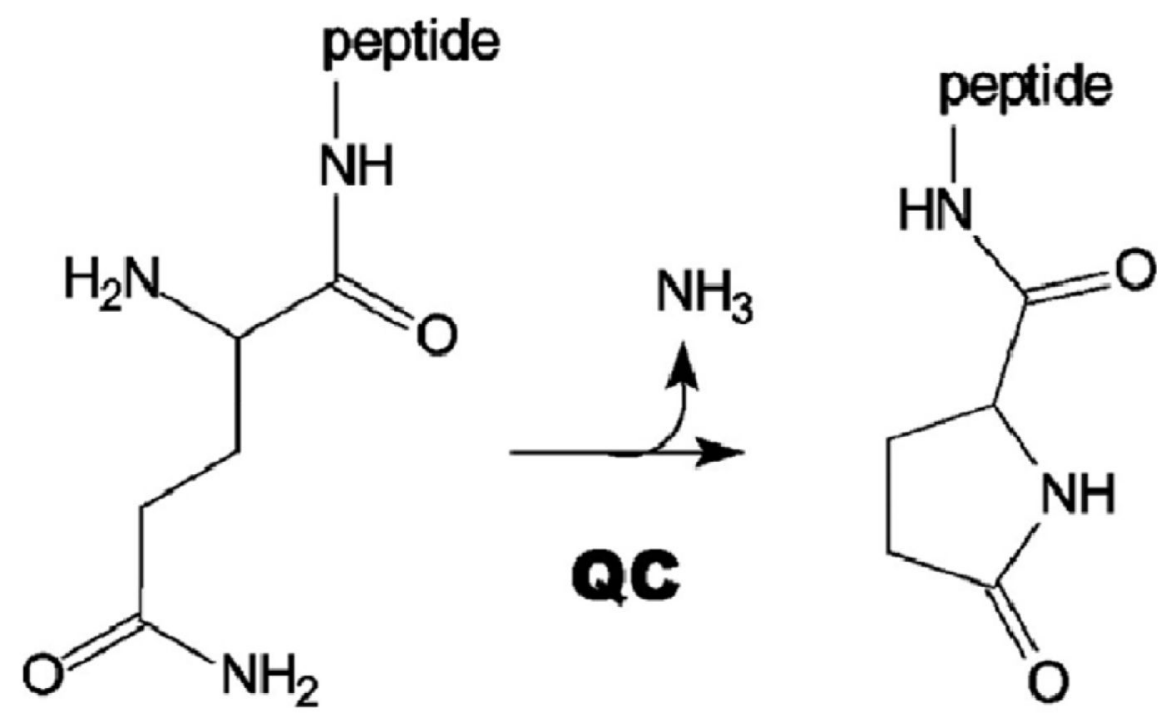

Figure 1.

Schematic representation of the conversion of L-glutaminylpeptide into 5-oxoprolylpeptide (pyroglutamyl-peptide) as catalyzed by glutaminyl cyclase (QC). 


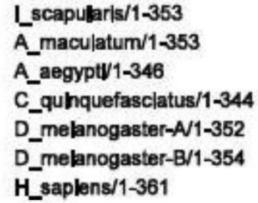

1_scapularis/1-353 A_maculatum/1-353 A_aegypty 1-346 C_quhquefasclatus/1-344 D melanogaster-A1-352 D_melanogaster-B/1-354 H_saplens/1-361

L_scapularis/1-353 A_maculatum/1-353 A_aegypty1-346 C_quhquefasclatus/1-344 D_melanogaster-A1-352 D_melanogaster-B/1-354 H_saplens/1-361

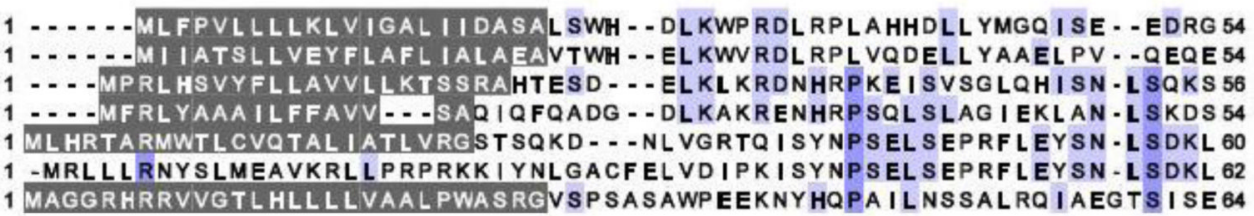

L_scapularis/1-353 A_maculatum/1-353 A_aogyptV1-346 C_quhquefasclatus/1-344 D_melanogaster-A1-352 D_melanogaster-B/1-354 H_sapiens/1361

L_scapularls/1-353 A_maculatum/1-353 A aegypt/1346 C_quhquefasclatus/1-344 D_melanogaster-A11352 D_melanogaster-B/1-354 H_saplens/1-361
55 DFNATLRNFLVPRVVGSQKHREVREFIVRSLK - - DLDWDVEEDCFDGQTP - HO I KPFCNVIATL 115 55 TFHDVLRHILVPRTVGSEGHAQVRQFIRTSLE - - DLGWHVEEDAFQASTP - LGTKGFS NVVATL 115 57 GLNEI L KHL L VERVVGTPG HENVKNY I VDYLR - - KL NWQVDL DEFEDETPTFGKL NFAN I GTL 118 55 DLKDVLKNL LVERVVGTAS HEKVRNY I AEYMR - - GLGWNVEVDEFEDETP IFGRLKFGNVIATL 116 61 HLREA I DK I L I PRVVGTT NHS I VREY I VQSLR - - DLDWDVEVNSF HDHAP I KGKL HFHN I I ATL 122 63 HLREA I DK I L I PRVVGTT NHS IVREY I VQSLR - - DLDWDVEVNSF HDHAP I KGKL HFHN I I A TL 124 65 MWQNDLQPLL I ERYPGSPGSYAARQHIMQR IQRL QADWVLEIDTFL SQTP-YGYRSFS N I ISTL 127

116 NPSACHRLVLACHYDSLLHK - - -EGTFIGATDSAVPCAQLLYLARSLNGKLQNQKTRGDG - - -L173 116 DT SACHRL VLACHYDSMVPK - - - YGEFLGATDSA VP CAQL IYLASVLNDKLKEQKRRGDG - - - I173 119 NPNAERFL VLACHYDSKYFK - - - DQVFIGATDSA VPCAMML DLAESLKAQFSKKKLDNS - - - - - 175 117 NPGAERF LVLACHYDSKYFK - - - NQVF I GATDSAVPCAMML NLASSMKSQLETKKSDKS - . - - L 173 123 NPNAERYLVLSCHYDSKYMP . . - GVEFLGATDSAVP CAMLLNLAQVLQEQLKPLKKSK . . . . - L 178 125 NPNAERYLVLSCHYDSKYMP - . - -GVEFLGATDSAVP CAMLL NLAQVLQEQLKPLKKSK - . . - - 180 128 NPTAKRHLVLACHYDSKYF S HWN NRVFVGATDSAVPCAMMLELARALDKKLLSLKTVSDSKPDL 191

\section{Lscapularis/1-353 A_maculatum/1-353 A_aegyptV1-346 \\ C_quhquefasclatus/1-344 D_melanogaster-A1-352 D_melanogaster-B/1-354 H saplens/1-361}

\begin{abstract}
174 TLQLVFFDGEEAFERWS S HDSL YGSRHL AQKWHEDRT SAERLESCLERSE I ANQ I DRMEVMVLL 237 174 TLQL I FFDGEEAFVRMSSSDSL YOSRHL ASMWHRNSTQSLLLEGCLPRSD IATQ IDRMEVLVLL 237 176 SLQLVFFDGEEAFHQWGPKDS IYGARHLAARWETE - . . . . . . . . . . . DKLKK I DMLVLL 222 174 SLQL I FFDGEEAFQQWGPKDS IYGARHLAARWESE - . . . . . . . . . . - GKLPRMDMLVLL 220 179 SLMLLFFDGEEAFEEWGPKDS I YGARHLAKKWHHE - . . . . . . . - . GKLDR I DMLVLL 225 181 SLMLLFFDGEEAFEEWGPKDS I YGARHLAKKWHHE - . . . . . . . . . . . . . . . 192 SLQL I FF DGEEA FL HWSPQDSL YGSRHLAAKMASTP HP PGARG . . . . . . . . . T SQL HGMDLLVLL 247
\end{abstract}

Figure 2.

Alignment of related QC sequences. QC amino acid sequences from two tick species ( $A$. maculatum and I. scapularis) were aligned with homologous genes. Residue shading is indicative of conserved residues. Red highlighted residues indicate zinc-binding, while green highlighted residues are involved in intermediate stabilization. 


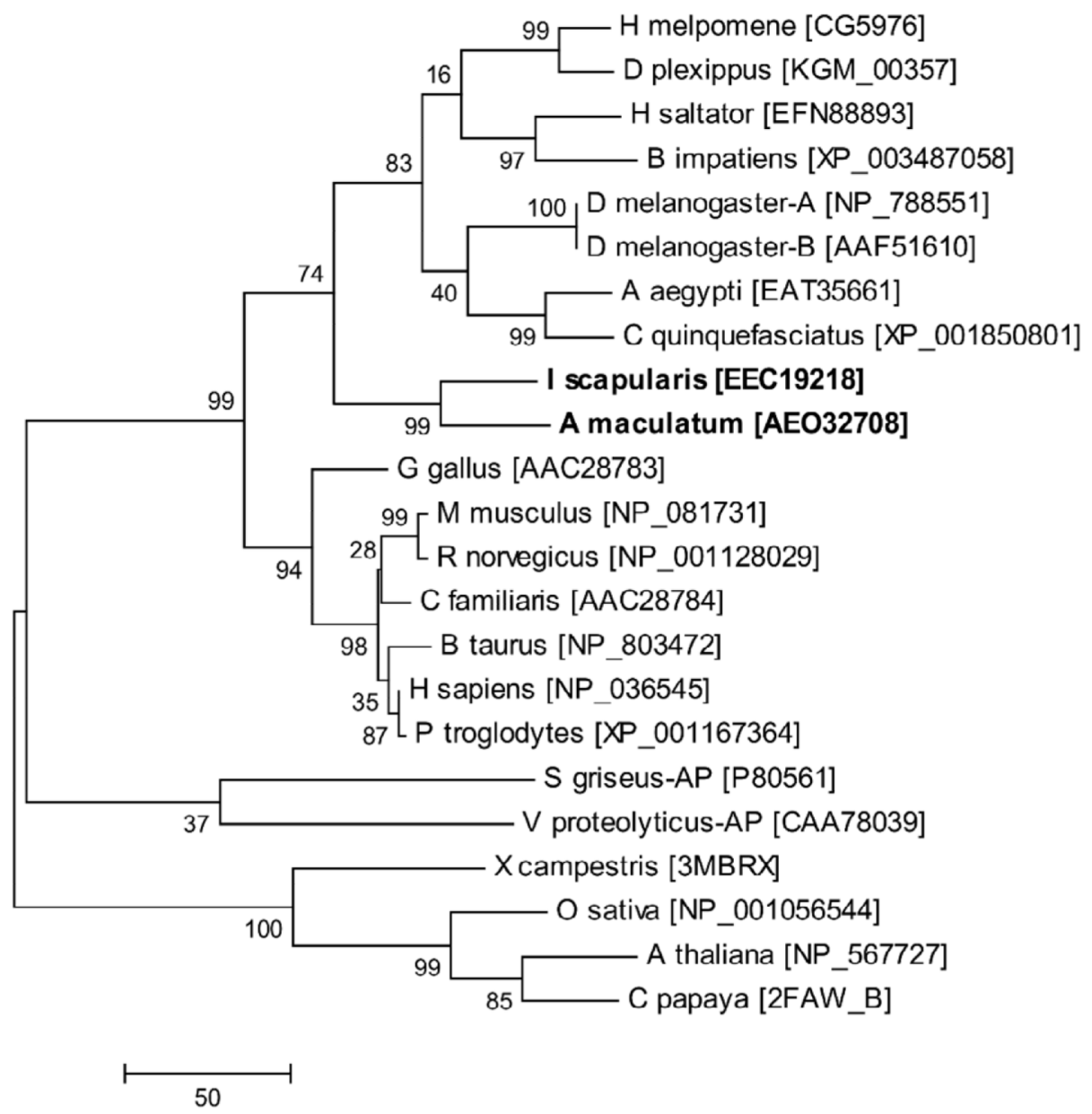

Figure 3.

The evolutionary history was inferred using the Maximum Parsimony method. Tree \#1 out of 10 most parsimonious trees (length $=1132$ ) is shown. The consistency index is $(0.833181)$, the retention index is $(0.812500)$, and the composite index is 0.681151 (0.676960) for all sites and parsimony-informative sites (in parentheses). The percentage of replicate trees in which the associated taxa clustered together in the bootstrap test (1000 replicates) is shown next to the branches. The MP tree was obtained using the CloseNeighbor-Interchange algorithm with search level 1 in which the initial trees were obtained with the random addition of sequences (10 replicates) (Nei and Kumar, 2000). The tree is drawn to scale, with branch lengths calculated using the average pathway method and are in the units of the number of changes over the whole sequence (Nei and Kumar, 2000). The analysis involved 23 amino acid sequences. All positions containing gaps and missing data were eliminated. There were a total of 196 positions in the final dataset. Evolutionary analyses were conducted in MEGA5 (Tamura et al., 2011). 
A

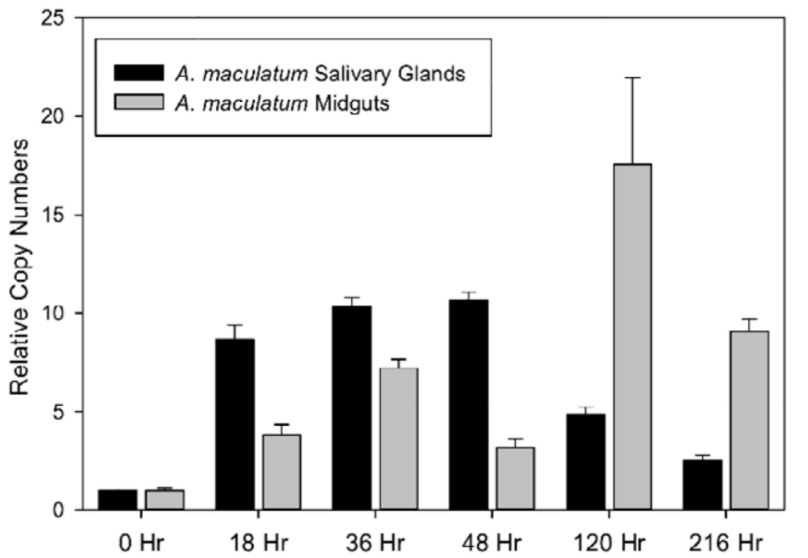

B

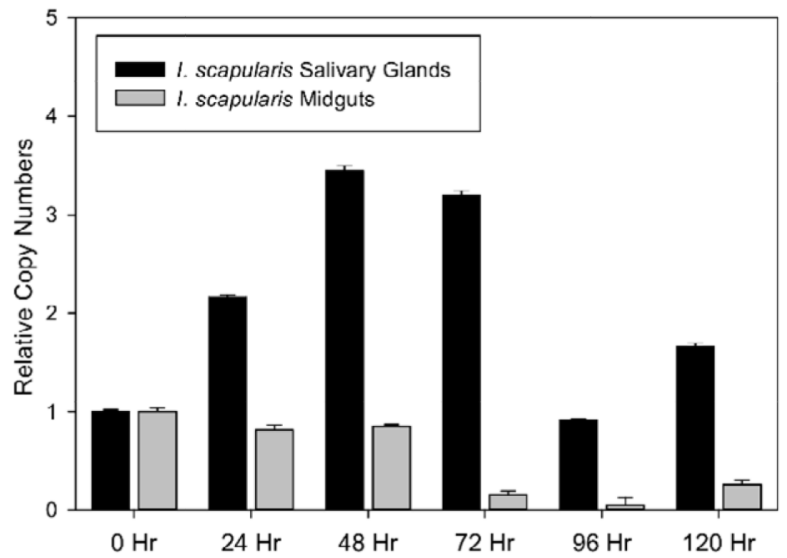

Figure 4.

Transcriptional gene expression of Glutaminyl Cyclase in the midgut and salivary glands during the blood-feeding on the host, A) adult female Amblyomma maculatum and B) Ixodes scapularis. It shows the difference in accumulation of transcripts for the tick QC both in the salivary glands and in the midgut tissues as feeding continues and when compared with the corresponding transcript abundance in tissues from unfed ticks. 
MI IATSLLVEYFLAFL IALAEAVTWHELKWVRDLRPLVQDELLYAA ELPVQEQETFHDVLRH ILVPRTVGSEGHAQVRQFIR TSLEDLGWH VEEDAFOASTPLGTK GFSNVVATLDTSACHRLVLACHYDSMVPKY GEFLGATDSAVPCAQL I YLASVLNDKLKEQKRRGDGITLQLIFFDG EEAFVRWSSSDSLYGSRHLASMWHRNSTQSLLLEGCLPRSDIATQI DRMEVLVLLDLLGAANPRFYSYFVDTRLVYDRFVEIESR ELNDMG AMTSCSRCR TNYFVNSSQLALIEDDHIPELR KNVPIVHVIPNPF PSVWHTRDDNAENLDHPT INNLNKIFKAFLTEYLRL

Figure 5.

Peptides identified by LC-MS-MS are underlined and represent $16 \%$ coverage. 

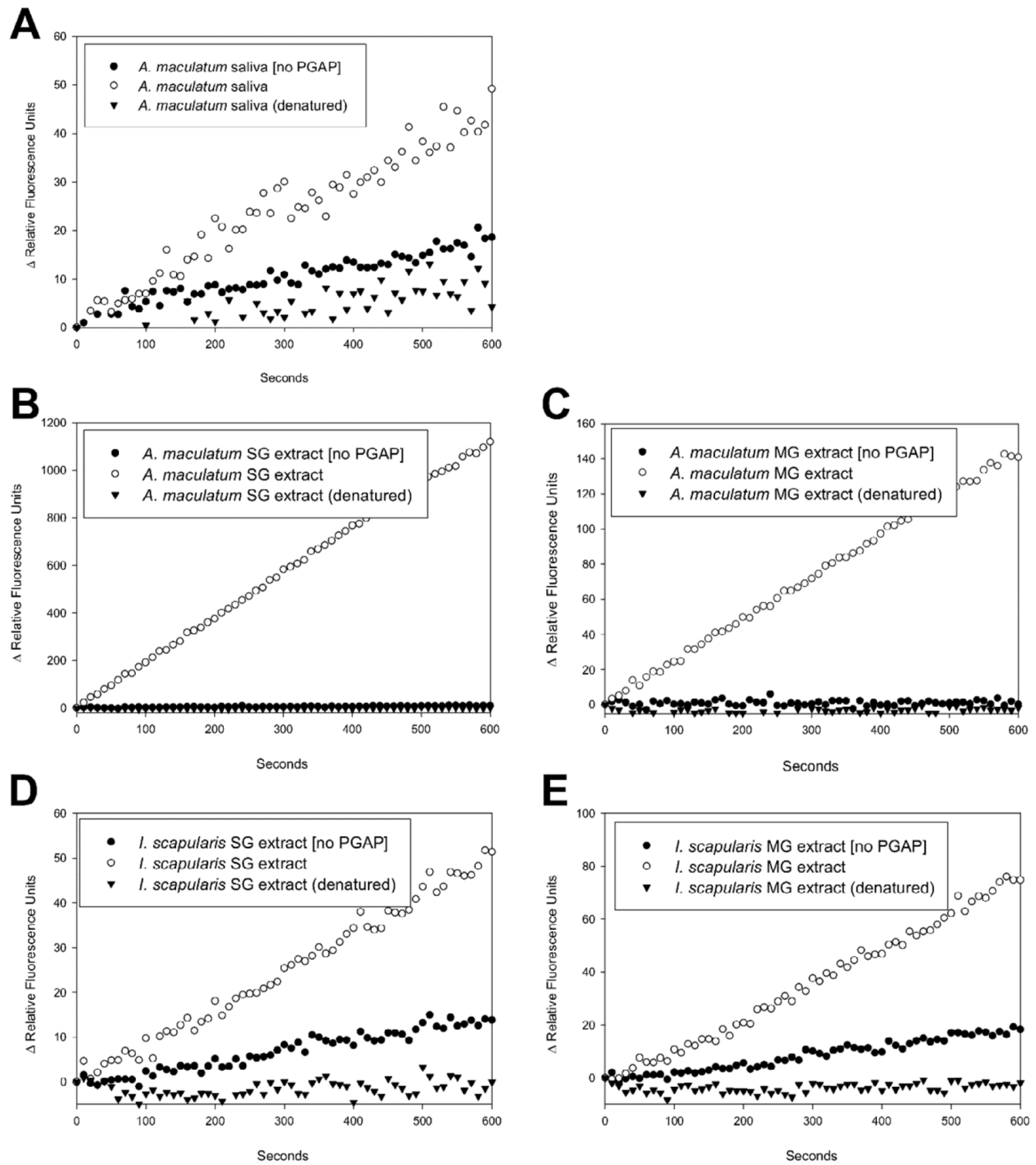

Figure 6.

QC enzymatic activity in $A$. maculatum saliva (A), $A$. maculatum SG extract (B), $A$. maculatum MG extract (C), I. scapularis SG extract (D) and I. scapularis MG extract (E) . 

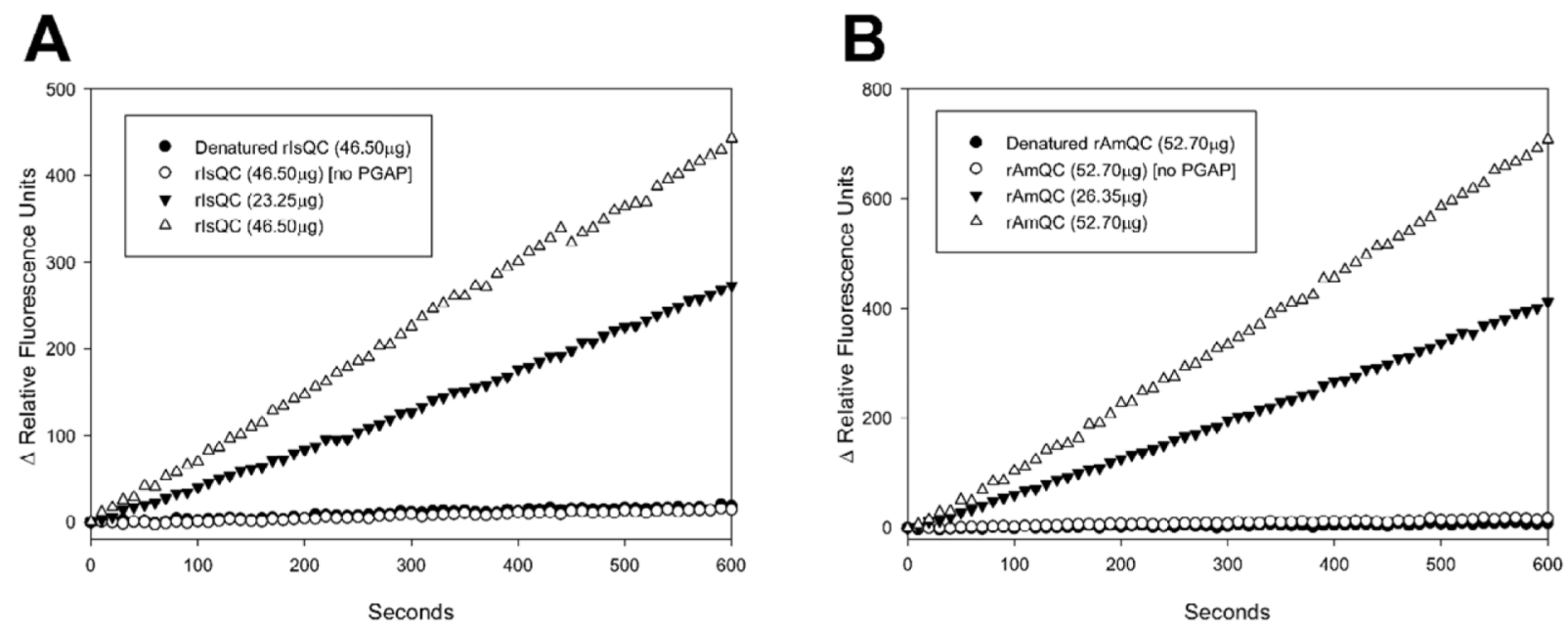

Figure 7.

Enzyme activity of recombinantly expressed QC from I. scapularis (A) and A. maculatum (B). 


\section{A QC Transcriptional Knockdown in Salivary Glands $\quad$ B}

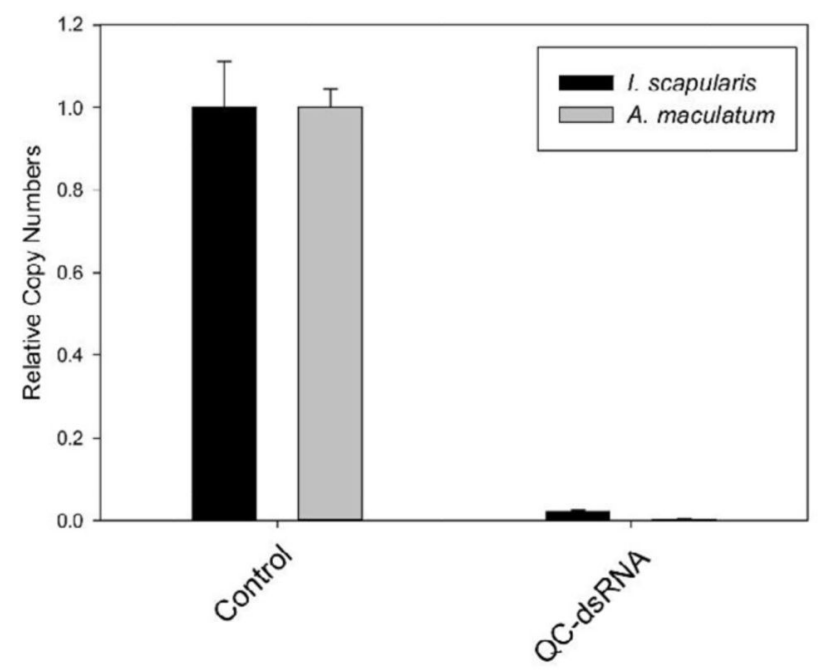

\begin{tabular}{|l|l|c|r|}
\hline \multicolumn{1}{|c|}{ Species } & \multicolumn{1}{c|}{ Group } & $\begin{array}{c}\text { Partially Fed Tick } \\
\text { Weight }(\mathrm{mg})\end{array}$ & Hatching \\
\hline \hline 1. scapularis & Mock injected & $71.9(\mathrm{n}=36)$ & ++++ \\
\hline 1. scapularis & GFP-dsRNA & $70.8(\mathrm{n}=20)$ & ++++ \\
\hline I. scapularis & QC-dsRNA & $27.3(\mathrm{n}=19)$ & None \\
\hline \hline A. maculatum & Mock injected & $105.0(\mathrm{n}=19)$ & ++++ \\
\hline A. maculatum & GFP-dsRNA & $46.7(\mathrm{n}=7)$ & ++++ \\
\hline A. maculatum & QC-dsRNA & $72.3(\mathrm{n}=13)$ & None \\
\hline
\end{tabular}

C

\section{GFP-dsRNA injected A. maculatum}

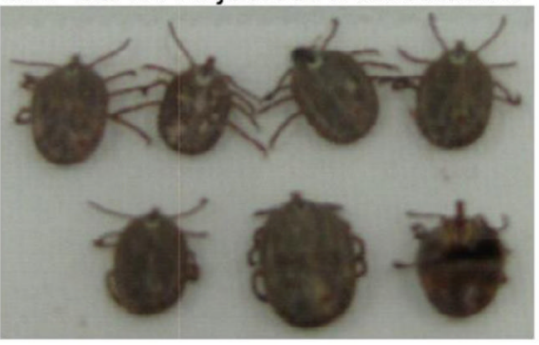

QC-dsRNA injected A. maculatum

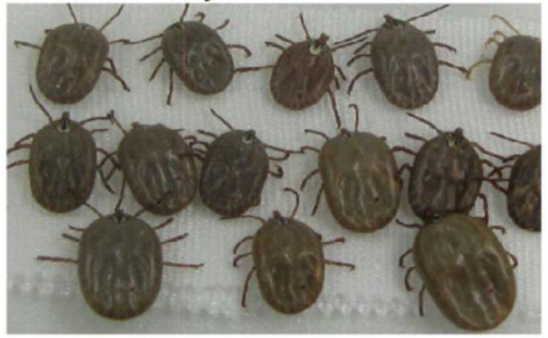

D

GFP-dsRNA injected $I$. scapularis

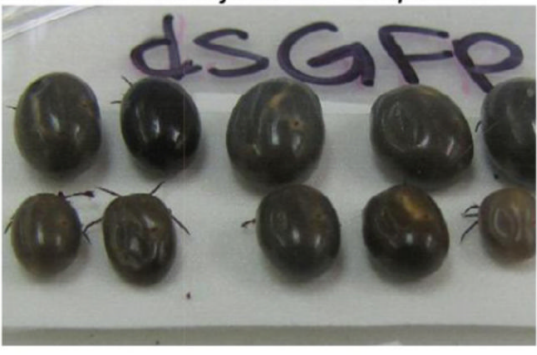

QC-dsRNA injected I. scapularis

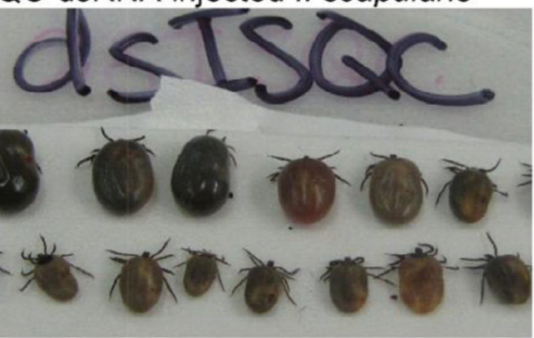

Figure 8.

A) Quantitative RT-PCR shows that the transcript of QC was efficiently diminished to more than $98 \%(\mathrm{p}<0.05)$ in both $I$. scapularis and $A$. maculatum. B) The mean partially engorged (Day 8) tick weights injected with QC-dsRNA in I. scapularis and A. maculatum. C) dsRNA-injected A. maculatum. D) dsRNA-injected I. scapularis. 
I. scapularis injected with GFP-dsRNA
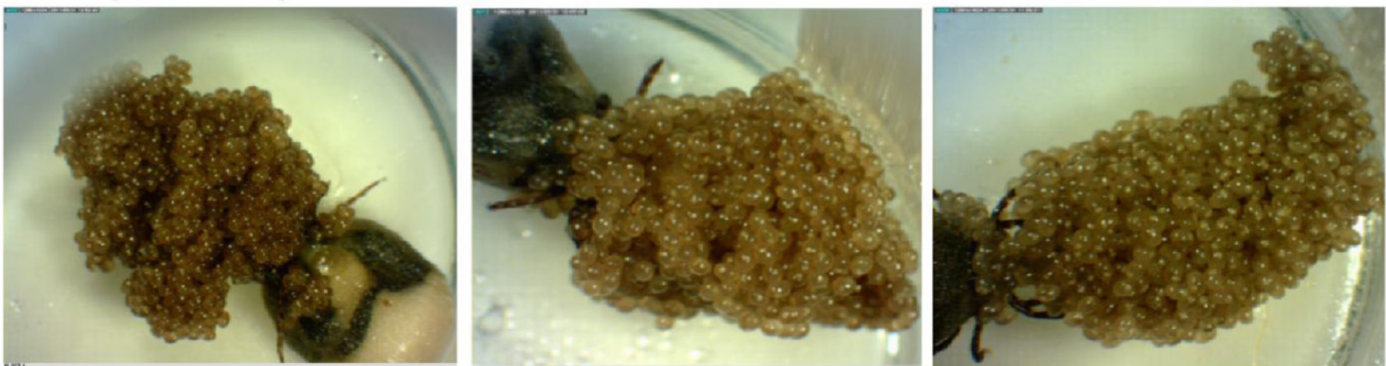

I. scapularis injected with QC-dsRNA
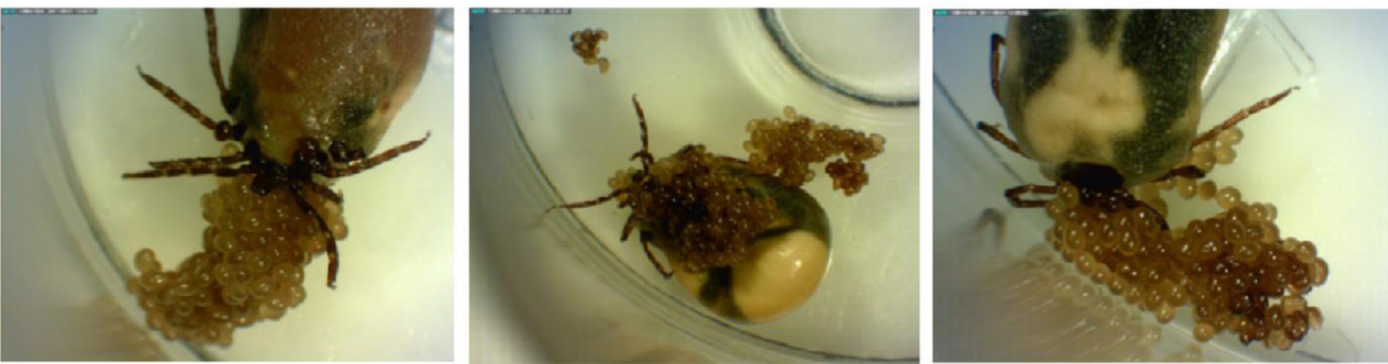

A. maculatum injected with GFP-dsRNA
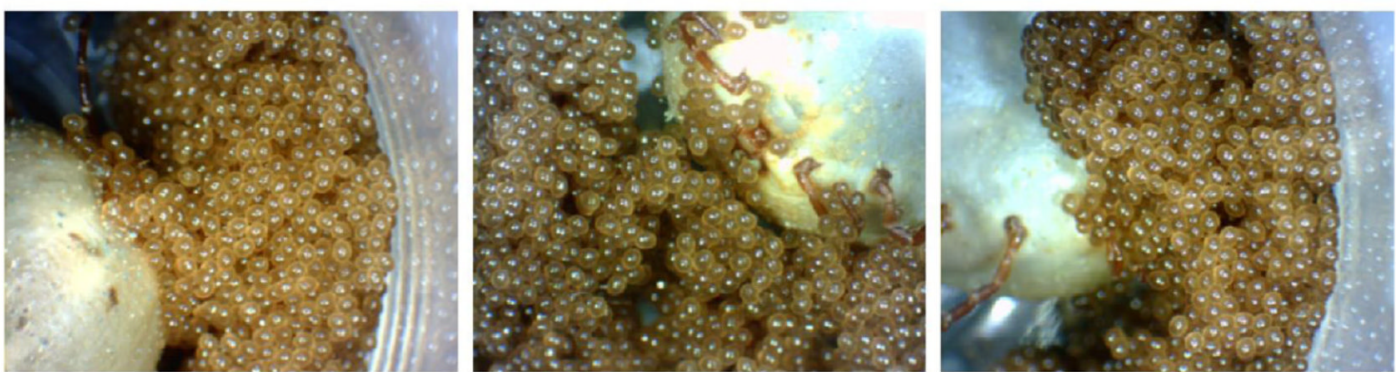

A. maculatum injected with QC-dsRNA
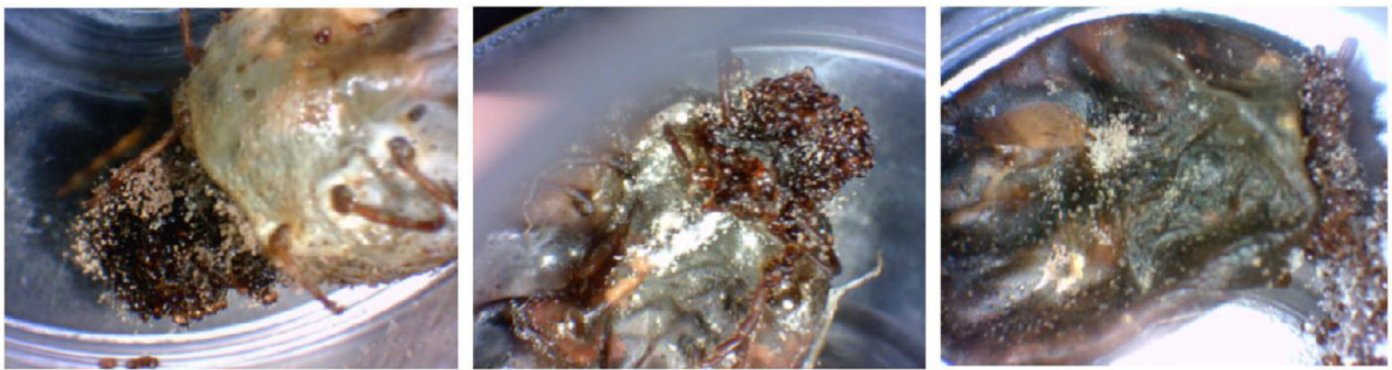

Figure 9.

Oviposition of ticks injected with QC-dsRNA or GFP-dsRNA. 

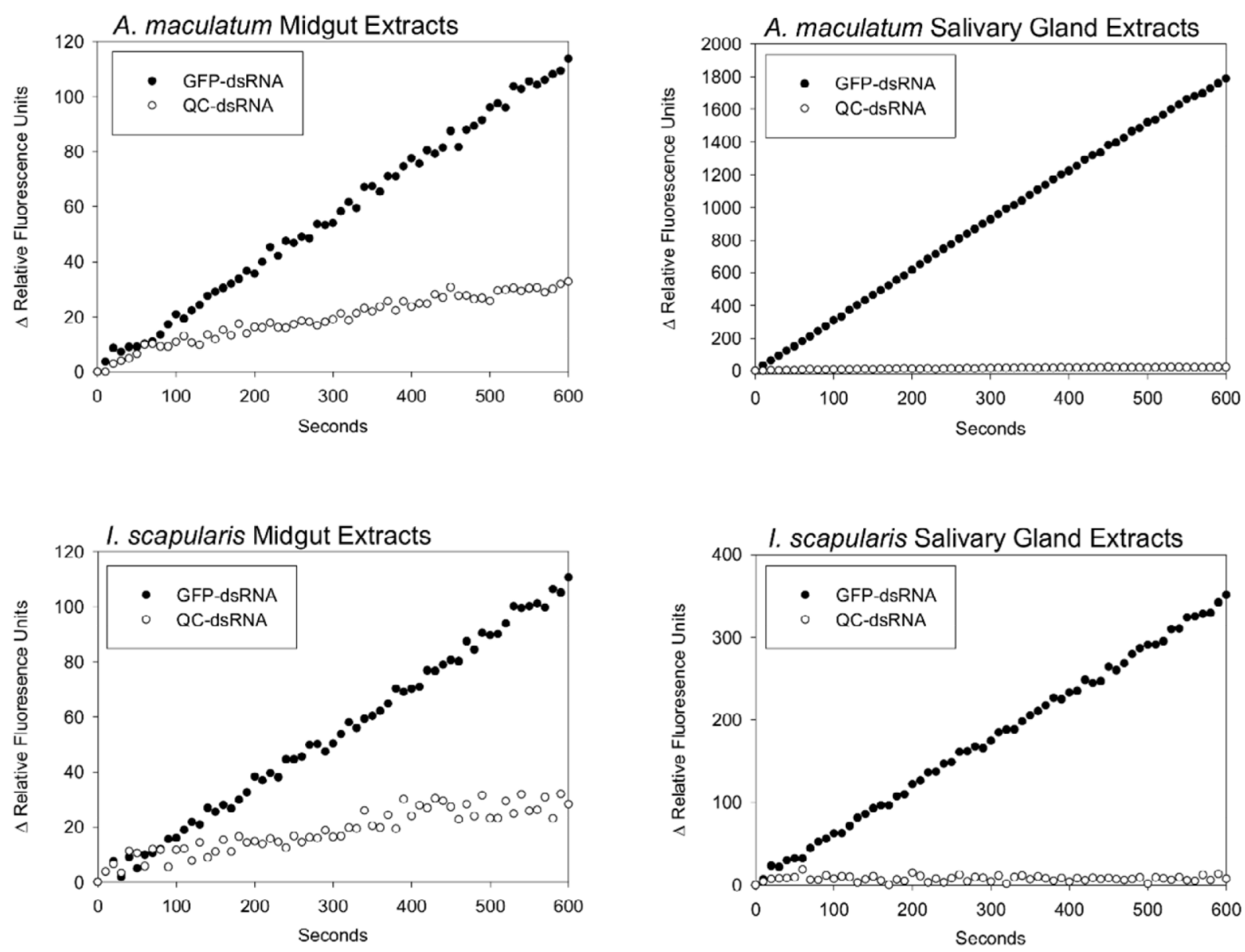

Figure 10.

QC activity in tick tissues injected with GFP-dsRNA or QC-dsRNA. 


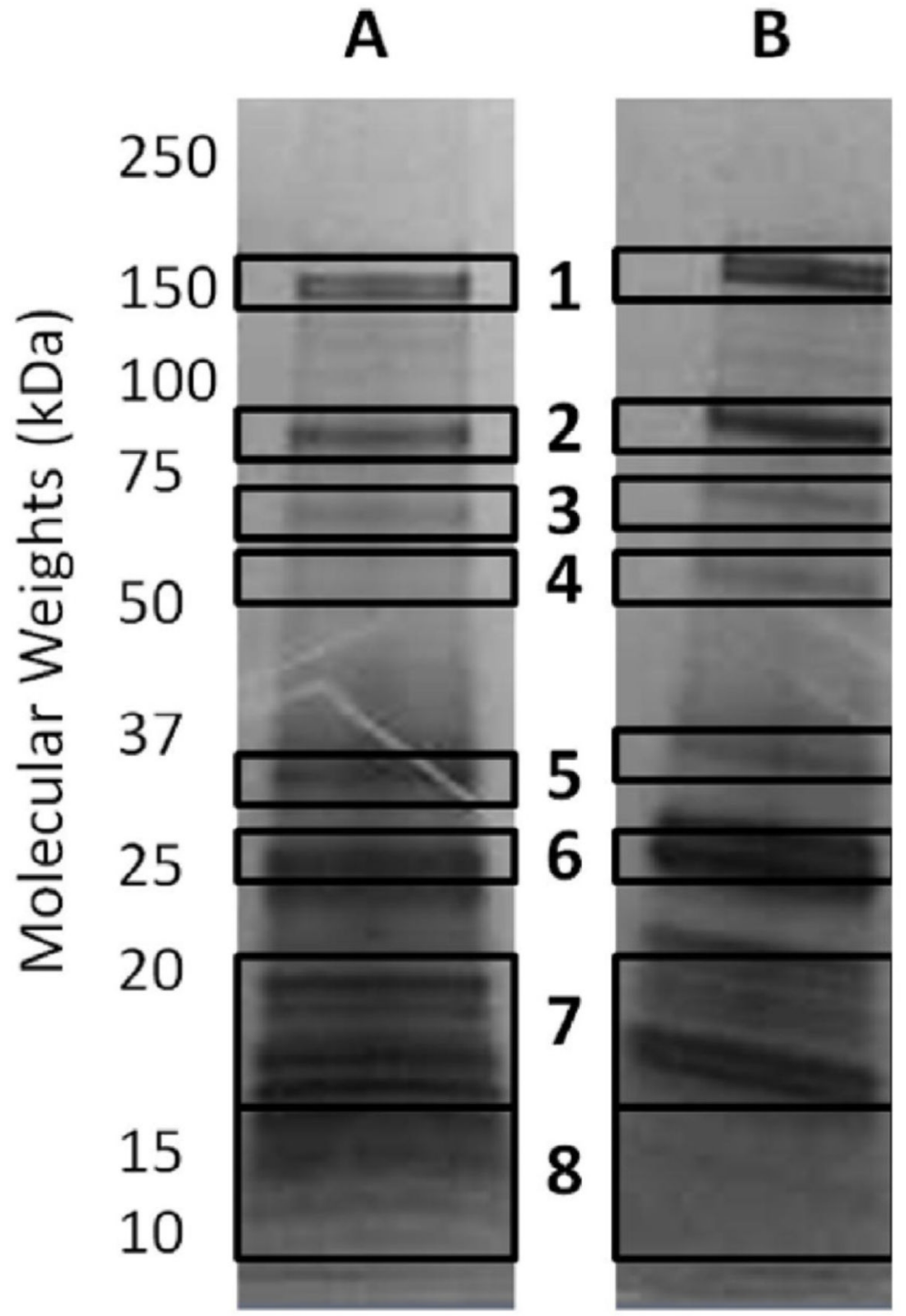

Figure 11.

Tick saliva collected from either mock-injected control ticks (A) or injected with QCdsRNA (B) was run on a 4-20\% SDS-PAGE and stained with Coomassie Blue. Strongly stained bands were excised (indicated by numbers) for protein identification using LC-MSMS. Please refer to Supplementary Table 1 for proteins identified in gel slices. 


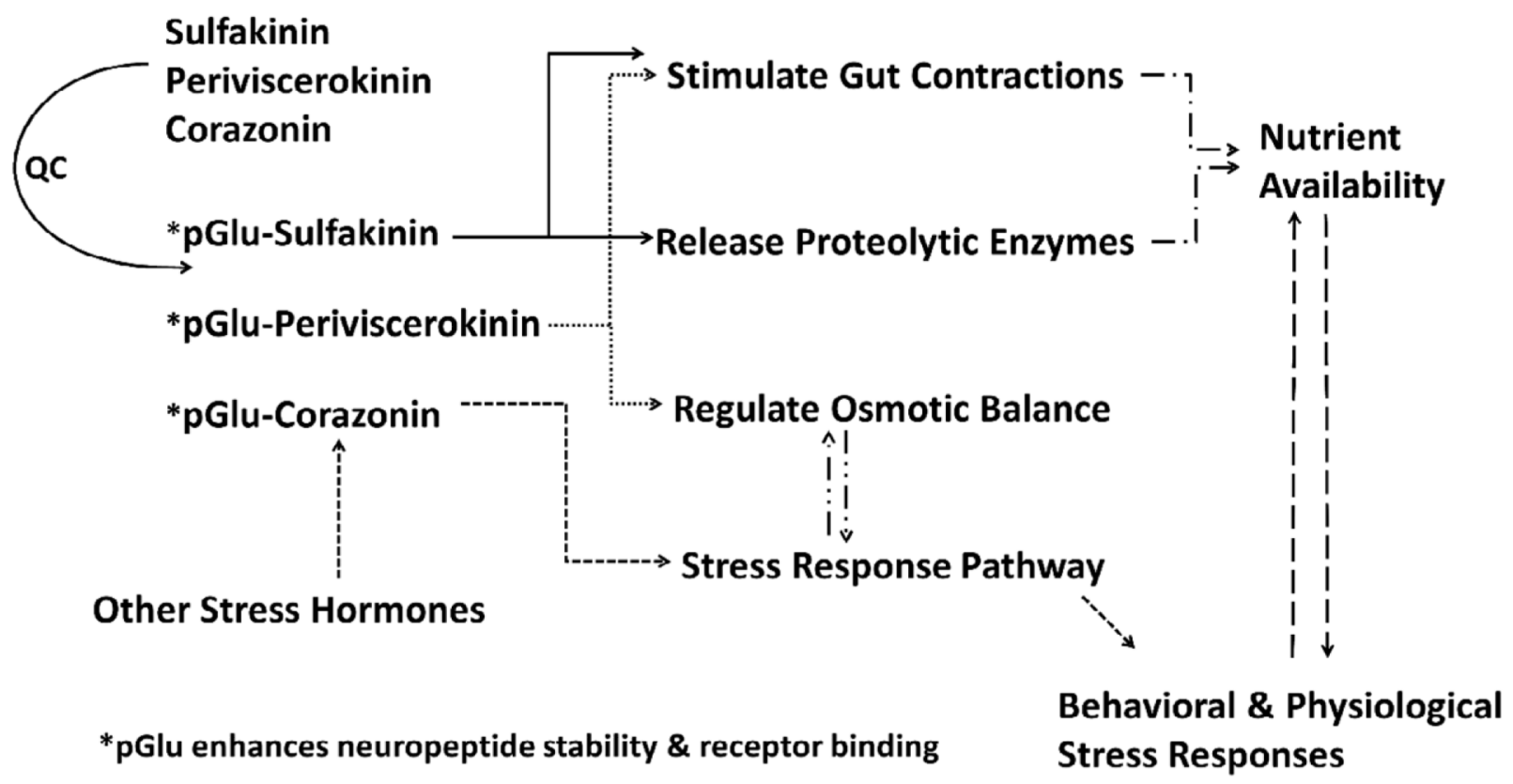

Figure 12.

Proposed Model for QC Processing Tick Neuropeptides. In this proposed model, QC catalyzes the formation of pyroglutamyl from the N-terminal Gln residue of three tick neuropeptides (sulfakinin, periviscerokinin, and corazonin). These tick neuropeptides affect tick physiology by stimulating gut contractions, releasing proteolytic enzymes, regulating osmotic balance, or as part of a general stress response. 

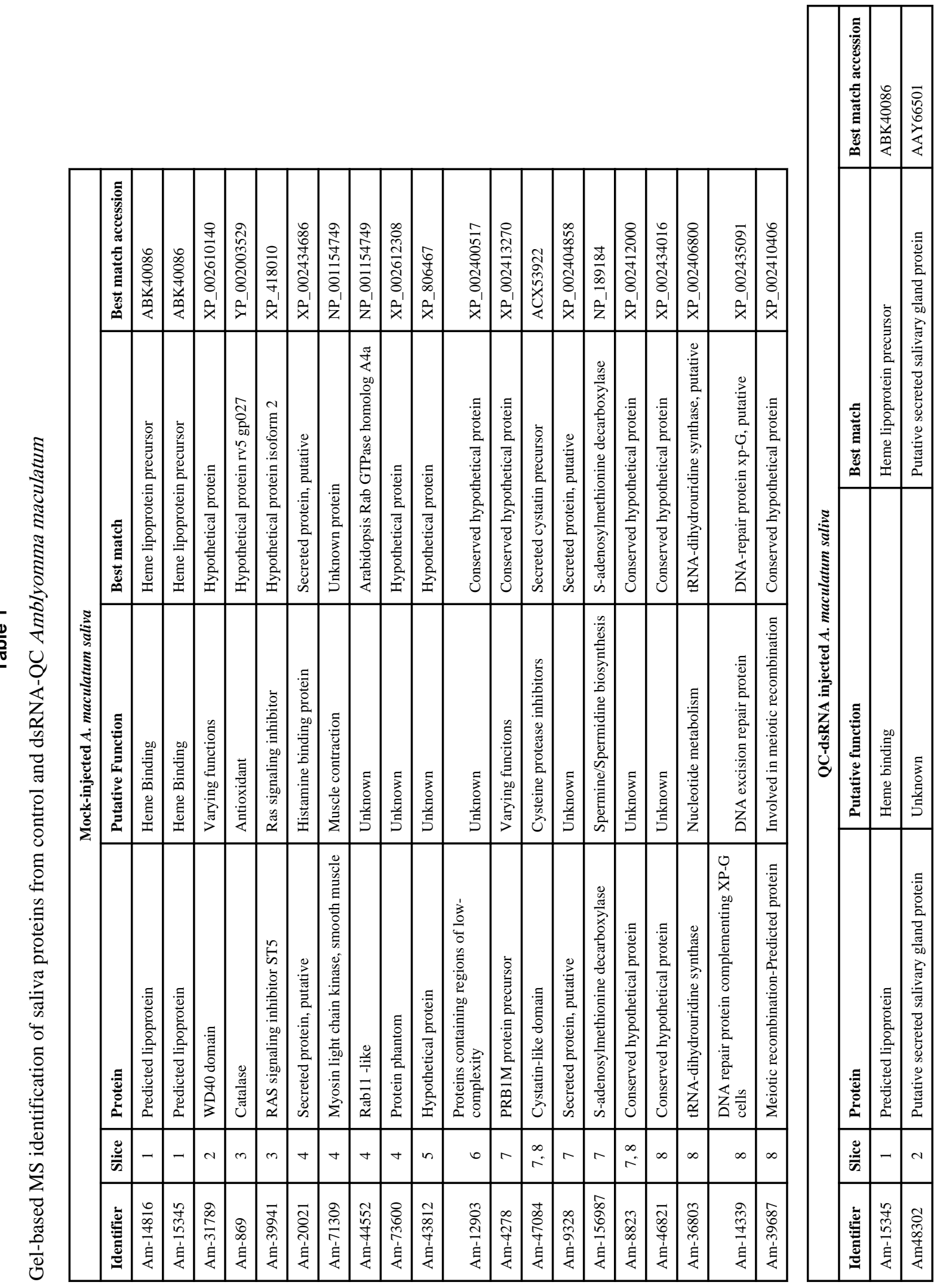


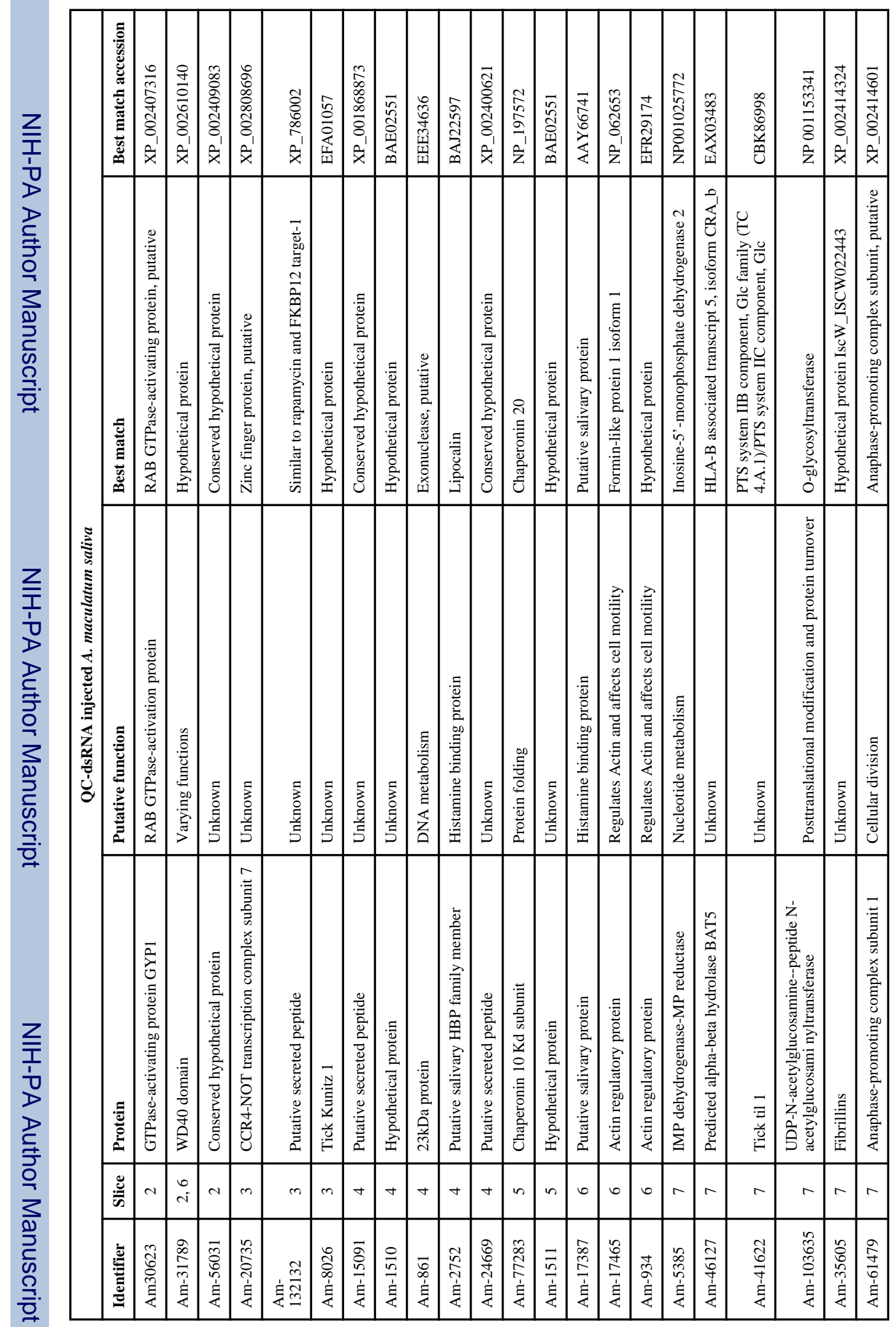

